\title{
Starvation: An Alternate Measure to Improve Immunity and Physiology of Red Sea Bream During Edwardsiella Tarda Infection
}

\author{
Sipra Mohapatra" ${ }^{1 \#}$, Tapas Chakraborty ${ }^{1 \# *}$, Rami Haj-Kacem², Sonoko Shimizu ${ }^{3}$, Takahiro Matsubara ${ }^{1}$ and Kohei Ohta ${ }^{1}$ \\ ${ }^{1}$ South Ehime Fisheries Research Center, Ehime University, Ainan, Japan \\ ${ }^{2}$ Department of Quantitative Methods, FSEGN, University of Tunis Carthage, Campus Universitaire, Mrezga, Nabeul, Tunisia \\ ${ }^{3}$ Fisheries Research Division, Ainan Town Office, 798-4211, Ainan, Japan \\ "equally contributed
}

\begin{abstract}
Dietary restrictions during infectious challenges are quite common in animal kingdom. In the present investigation, we aimed to explore the positive implications of short-term starvation in Edwardsiella tarda infected red sea breams. Starvation resulted in depleted transcription of several iron binding protein (Hepcidin, Transferrin), which could have reduced the bacterial colonization in starved- infected fish. This was confirmed by the significantly $(P<0.05)$ low bacterial load in the spleen and muscle of starved-infected fish. Gills showed mild damage to the secondary filaments architecture as well as elevated mucus production in the starved-infected fish compared to the fed ones. Massive mucus cell hyperplasia was observed in starved-placebo fish, which further increased after infection. Decreased activities of serum anti-oxidative enzymes and reduced total antioxidant capacity after starvation was suggestive of improved stress response and heightened stress withstanding capacity of these fish. Relatively higher haemoglobin and phagocytic activity along with the increased cytokines (TNF $\alpha, I L-1 \beta$ ) level in starved-infected groups than their fed counterparts indicated the better immune condition of the former group. Additionally, our data also demonstrated that starvation enhanced the survivability and overall disease resistance index of infected fish, indicating that short period of starvation might be a beneficial measure to fight against infections.
\end{abstract}

Keywords: Starvation; Edwardsiella tarda; Red sea bream; Cytokines; Gill mucus production; Iron homeostasis

\section{Introduction}

Edwardsiella tarda, a gram negative pathogenic bacteria, is known to affect both fresh and marine aquaculture of many economically valued fish, especially tilapia (Oreochromis niloticus), carp (Labeo rohita), channel catfish (Ictalurus punctatus), red sea bream (Pagrus major) and turbot (Psetta maxima) [1-4]. Despite the success of vaccination in fish disease prevention, till date, no effective vaccine has been developed and commercially marketed for E. tarda control [4]. In addition, plenty of reports suggest that the effect of $E$. tarda varies between fish species [5]. Hence in such complicated situation, the exigencies for alternative preventive measures increase exponentially in order toantagonize the losses incurred due to $E$. tarda infection.

The voluntary curtailment in food intake during infection is known to increase the survivability in various organisms [6], as excessive nutrition is often detrimental for immune homeostasis [7]. Anson et al. [8] reported that the infected mice that were unable to reduce their food intake suffered increased mortality, while the intermittent fasted mice showed increased glucose metabolism, neuronal resistance and lesser susceptibility to injury. Although the details vary across host species and type of pathogen [9], non-acceptance of food during any infection is highly modulated by the host's own immune-neural connections [10], and allows the animal to manipulate its complex physiological interconnections into a state that supports enhanced immune function [11].

Food restriction or starvation, and infection are both instrumental in changing various metabolic pathways in Atlantic salmon [12]. Reduction of food intake triggers the general defense response of fish, allotting energy or other resources to defeat the illness. Upon fasting, significant reduction in the rate of mortality was observed in the Vibrio salmonicida infected Atlantic salmon (Salmo salar) [13] and Edwardsiella ictaluri infected Channel catfish [14]. Food restriction is also known to reduce the free metal ion circulation in the body due to subdued intake. Since free iron is very essential for the growth and propagation of infectious agents, its curtailment might be an essential tool in reducing the rate of infection and further increasing the survivability of the fish. Starvation also results in theinduction of Hepcidin (an antimicrobial peptide and iron regulator) level, which further enhances the iron sequestering mechanism, leading to a reduction in the free iron content in the body. The dual function of Hepcidin as an antimicrobial peptide and iron homeostasis regulator establishes the linkage between the infection, iron metabolism and nutrient availability. Hepcidin induction was also found be strongly induced by the pro-inflammatory cytokines in mice, after viral and bacterial infections [15]. Numerous studies show that change in macrophages, cytokines and their associated signaling after calorie restriction is helpful in decreasing the chronic inflammation [16].

Red sea bream is a highly valued fish and an excellent candidate for commercial aquaculture as well as sports fisheries. However, in recent years, red sea bream aquaculture has been plagued by numerous diseases, with E. tarda infection being the most prevalent [5]. Thus, in the present investigation, we have tried to exemplify the effect of starvation on the immune profile, transcriptional alterations, gill tissue integrity and survivability of $E$. tarda infected red sea bream.

*Corresponding author: Tapas Chakraborty, South Ehime Fisheries Research Center, Ehime University, Ainan, Japan, Tel: +81 89573 7112; Fax: +81 89573 7113; E-mail: chakraborty.tapas.yx@ehime-u.ac.jp

Received May 20, 2016; Accepted June 10, 2016; Published June 12, 2016

Citation: Mohapatra S, Chakraborty T, Kacem RH, Shimizu S, Matsubara T, et al. (2016) Starvation: An Alternate Measure to Improve Immunity and Physiology of Red Sea Bream During Edwardsiella Tarda Infection. J Aquac Res Development S2: 007. doi:10.4172/2155-9546.S2-007

Copyright: (c) 2016 Mohapatra S, et al. This is an open-access article distributed under the terms of the Creative Commons Attribution License, which permits unrestricted use, distribution, and reproduction in any medium, provided the original author and source are credited. 


\section{Materials and Methods}

\section{Laboratory culture and preparation of pathogen}

Pure strain of E. tarda was obtained from Ainan Town Office (Fisheries Research Division), re-grown on Salmonella-Shigella (SS) Agar media (Nissui Pharmaceutical, Japan) and used for inoculum preparation using previously published protocol [17]. Concisely, the SS agar media was dissolved in distilled water and centrifuged at $200 \mathrm{xg}$ for $1 \mathrm{~min}$ in order to remove the agar. The supernatant (SS liquid broth) was collected and autoclaved. Freshly grown pure bacterium was inoculated into the SS liquid media, incubated for $72-96 \mathrm{~h}$ at $28^{\circ} \mathrm{C}$, and thereafter centrifuged at $2400 \mathrm{xg}$ for $15 \mathrm{~min}$ at $4^{\circ} \mathrm{C}$ to harvest the $E$. tarda. The pellets were thoroughly washed in phosphate buffer saline (PBS; pH 7.2), re-suspended in PBS, and the optical density at OD600 was measured and also subsequently diluted to quantify the number of viable colony forming units (CFU) by spread plate method [18]. Ultimately, a bacterial concentration of $10^{9} \mathrm{CFU} \mathrm{mL} \mathrm{m}^{-1}$ was added to the water.

\section{Fish husbandry and experimental design}

Four month old red sea breams $(24 \mathrm{~g} \pm 0.24)$ were procured from Yasutaka Suisan Company, and conditioned in flow-through sea water system with commercial diet (Otohime EP, Marubeni Nisshin Feed Co. Ltd., Japan). Two weeks after conditioning, the fish were transferred to eight different tanks (Tank 1-8) with two replicates each (stocking density of 20 fish per tank). The experimental fish were kept in $500 \mathrm{~L}$ capacity flow-through fiber-reinforced tanks $(300 \mathrm{~L}$ water holding capacity) with a flow rate of $1 \mathrm{~L} \mathrm{~min}^{-1}$. The water temperature in all the tanks was maintained at $25-26^{\circ} \mathrm{C}$ throughout the experimental period. Half of the fish (Tank 1-4) were fed twice a day, at the rate of $2.5 \%$ of body weight for 10 days, while the other half (Tank 5-8) were continuously starved. After 10 days, half of the fed (Tank 3 and 4 ) and starved group (Tank 7 and 8) fish were immersed in E. tarda infected water (final concentration $10^{9} \mathrm{CFU} \mathrm{mL}^{-1}$ ) for $5 \mathrm{~h}$ and named as fedinfected and starved-infected, respectively. The remaining fish were immersed in seawater containing sterilized SS media and renamed accordingly (Tank 1 and 2, fed-placebo; Tank 5 and 6, starvedplacebo). Following pathogenic/placebo infection, the fish were grown in pathogen-free flow-through seawater for 10 more days, following the same feeding regime under $12 \mathrm{~h}$ light and $12 \mathrm{~h}$ darkness cycle. All the groups were immediately sampled after $5 \mathrm{~h}$ of immersion (0 dai (days after infection)) and further timely sampled on the $5^{\text {th }}$ and $10^{\text {th }}$ days after infection (represented as 5 and 10 dai, respectively).

\section{Sample collection}

At each sampling point, four fish from each group were anesthetized with clove oil ( $\left.50 \mu \mathrm{L} \mathrm{L}^{-1}\right)$ (Wako, Japan) and blood was collected using a heparin-coated syringe. The blood was kept in heparin- coated eppendorf tubes and immediately used for analysis. For serum, blood was collected without any anti-coagulant, and transferred to nonheparin-coated eppendorf tubes. The blood was allowed to clot for 3 $\mathrm{h}$ and thereafter centrifuged at $3500 \mathrm{xg}$ for $15 \mathrm{~min}$. The supernatant was collected and stored at $-30^{\circ} \mathrm{C}$ for future use. Immediately after blood collection, the unconscious fish were euthanized by cervical transection followed by pithing method, and dissected to collect the organs for various analyses. Portions of liver, spleen and kidney were stored in RNAlater for Real-time PCR analysis, and some were used for enzymatic analysis. Parts of gills were kept in Bouin solution for the histological observations.

\section{Bacterial population analysis}

DNA was isolated from the samples (stored at $-80^{\circ} \mathrm{C}$ by snapfreezing) using DN easy Blood and Tissue kit (Qiagen, USA), following manufacturer's protocol. After quantification of DNA, 10ng of each sample was analyzed by Real-time PCR using SSO fast probe mix and E. tarda specific primers (Supplementary Table 1), following manufacturer's protocol

\section{Blood and serum analysis}

The circulating blood glucose and total haemoglobin contents were assessed using Glucose colorimetric assay kit (Cayman, USA) and haemoglobin colorimetric assay kit (Cayman, USA), respectively, using manufacturer's instructions. The Phagocytic activity (the respiratory burst activity, NBT) was measured using fresh blood samples following previously published protocol (Mohapatra et al., 2014a)

Total protein, Albumin, SOD (Superoxide dismutase), CAT (Catalase), GPX (Glutathione peroxidase) and Total anti-oxidation capacity (TAC) were, respectively, measured using Protein assay kit (Abnova), BCP albumin assay kit (Abnova), SOD assay kit-WST (Dojindo, Japan), Catalase assay kit (Abnova), GPX assay kit (Biovision, USA) and Total antioxidant capacity assay (TAC) kit (Biovision, USA) kits, following the manufacturer's protocol. The globulin amount was calculated by deducting the albumin amount from the total protein content (19). The small molecule anti-oxidation (SMC) and protein anti-oxidation capacity (PAC) were further calculated from the TAC values.

\begin{tabular}{|c|c|c|c|c|c|c|c|c|c|c|c|c|c|c|c|c|c|}
\hline \multirow{2}{*}{ Parameters } & & \multicolumn{3}{|c|}{ Placebo } & \multirow{2}{*}{$\begin{array}{c}\text { Mean } \\
\text { Placebo }\end{array}$} & \multicolumn{3}{|c|}{ Infected } & \multirow{2}{*}{$\begin{array}{c}\text { Mean } \\
\text { Infected }\end{array}$} & \multirow{2}{*}{$\begin{array}{l}\text { Overall } \\
\text { Mean }\end{array}$} & \multicolumn{7}{|c|}{ Significance $(P<0.05)$ by three way ANOVA } \\
\hline & & T0 & T5 & T10 & & T0 & T5 & T10 & & & St & $\mathrm{T}$ & 1 & StT & Stl & $\mathrm{TI}$ & StTI \\
\hline \multirow{3}{*}{ CAT } & Fed & $\begin{array}{l}0.01 \pm \\
0.00^{\mathrm{ab}}\end{array}$ & $\begin{array}{c}0.00 \pm \\
0.00^{\mathrm{a}}\end{array}$ & $\begin{array}{l}0.01 \pm \\
0.00^{\mathrm{ab}}\end{array}$ & $\begin{array}{c}0.01 \pm \\
0.00^{\mathrm{A}}\end{array}$ & $\begin{array}{l}0.01 \pm \\
0.00^{\mathrm{ab}}\end{array}$ & $\begin{array}{c}0.02 \pm \\
0.00^{\mathrm{b}}\end{array}$ & $\begin{array}{c}0.03 \pm \\
0.00^{c}\end{array}$ & $\begin{array}{c}0.02 \pm \\
0.00^{\mathrm{B}}\end{array}$ & $\begin{array}{l}0.01 \pm \\
0.00^{x}\end{array}$ & \multirow{3}{*}{$S$} & \multirow{3}{*}{$\mathrm{S}$} & \multirow{3}{*}{ S } & \multirow{3}{*}{ NS } & \multirow{3}{*}{ NS } & \multirow{3}{*}{ S } & \multirow{3}{*}{ S } \\
\hline & Starved & $\begin{array}{c}0.00 \pm \\
0.00^{\mathrm{a}}\end{array}$ & $\begin{array}{c}0.00 \pm \\
0.00^{\mathrm{a}}\end{array}$ & $\begin{array}{l}0.01 \pm \\
0.00^{\mathrm{ab}}\end{array}$ & $\begin{array}{c}0.01 \pm \\
0.00^{\AA}\end{array}$ & $\begin{array}{c}0.01 \pm \\
0.00^{\mathrm{a}}\end{array}$ & $\begin{array}{l}0.02 \pm \\
0.00^{\mathrm{ab}}\end{array}$ & $\begin{array}{l}0.02 \pm \\
0.00^{\mathrm{ab}}\end{array}$ & $\begin{array}{c}0.02 \pm \\
0.00^{\mathrm{B}}\end{array}$ & $\begin{array}{l}0.01 \pm \\
0.03^{\curlyvee}\end{array}$ & & & & & & & \\
\hline & Mean & $0.00 \pm 0.00$ & $\begin{array}{c}0.00 \pm \\
0.00\end{array}$ & $\begin{array}{c}0.01 \pm \\
0.00\end{array}$ & $\begin{array}{l}0.01 \pm \\
0.00^{\mathrm{M}}\end{array}$ & $\begin{array}{c}0.01 \pm \\
0.00\end{array}$ & $\begin{array}{c}0.02 \pm \\
0.00\end{array}$ & $\begin{array}{c}0.03 \pm \\
0.00\end{array}$ & $\begin{array}{l}0.02 \pm \\
0.00^{N}\end{array}$ & & & & & & & & \\
\hline \multirow{3}{*}{ SOD } & Fed & $\begin{array}{c}0.03 \pm \\
0.00^{\mathrm{b}}\end{array}$ & $\begin{array}{l}0.05 \pm \\
0.01^{\text {bc }}\end{array}$ & $\begin{array}{l}0.03 \pm \\
0.00^{\mathrm{ab}}\end{array}$ & $\begin{array}{c}0.04 \pm \\
0.00^{\mathrm{B}}\end{array}$ & $\begin{array}{c}0.07 \pm \\
0.00^{\mathrm{c}}\end{array}$ & $\begin{array}{l}0.05 \pm \\
0.00^{\text {bc }}\end{array}$ & $\begin{array}{c}0.07 \pm \\
0.01^{\mathrm{c}}\end{array}$ & $\begin{array}{c}0.06 \pm \\
0.00^{\mathrm{D}}\end{array}$ & $\begin{array}{c}0.05 \pm \\
0.00^{x}\end{array}$ & \multirow{3}{*}{ NS } & \multirow{3}{*}{$\mathrm{S}$} & \multirow{3}{*}{ S } & \multirow{3}{*}{$\mathrm{S}$} & \multirow{3}{*}{ NS } & \multirow{3}{*}{$S$} & \multirow{3}{*}{ NS } \\
\hline & Starved & $\begin{array}{c}0.02 \pm \\
0.00^{\mathrm{a}}\end{array}$ & $\begin{array}{l}0.03 \pm \\
0.00^{\mathrm{ab}}\end{array}$ & $\begin{array}{c}0.04 \pm \\
0.00^{\mathrm{b}}\end{array}$ & $\begin{array}{c}0.03 \pm \\
0.00^{A}\end{array}$ & $\begin{array}{l}0.00 \pm \\
0.00^{\mathrm{ab}}\end{array}$ & $\begin{array}{c}0.08 \pm \\
0.02^{\mathrm{c}}\end{array}$ & $\begin{array}{c}0.07 \pm \\
0.00^{\mathrm{c}}\end{array}$ & $\begin{array}{l}0.05 \pm \\
0.01^{\mathrm{BC}}\end{array}$ & $\begin{array}{l}0.04 \pm \\
0.00^{x}\end{array}$ & & & & & & & \\
\hline & Mean & $0.03 \pm 0.00$ & $\begin{array}{c}0.04 \pm \\
0.01\end{array}$ & $\begin{array}{c}0.03 \pm \\
0.00\end{array}$ & $\begin{array}{c}0.03 \pm \\
0.00^{\mathrm{M}}\end{array}$ & $\begin{array}{c}0.03 \pm \\
0.00\end{array}$ & $\begin{array}{c}0.06 \pm \\
0.01\end{array}$ & $\begin{array}{c}0.07 \pm \\
0.01\end{array}$ & $\begin{array}{c}0.05 \pm \\
0.01^{\mathrm{N}}\end{array}$ & & & & & & & & \\
\hline
\end{tabular}

Data expressed as mean \pm SE $(n=4)$. All significance are measured at $P<0.05$. Different small superscript $(a, b, c, d$, etc.) represent the level of significance among different treatment groups at different sampling points for a particular parameter. Different capital superscript $(A, B, C)$ represents significant difference between means of different experimental groups (fed-placebo, starved-placebo, fed-infected and starved-infected groups). Overall mean value having different capital superscript ( $\mathrm{M} \& \mathrm{~N}, \mathrm{X}$ $\&$ Y) vary significantly. S-Significant, NS-Non-significant. Units: Catalase (CAT) - units $\mathrm{mg}$ protein $^{-1}$; Superoxide dismutase (SOD) - units mg protein ${ }^{-1}$

Table 1: Effect of starvation (St), E. tarda infection (I), treatment time $(\mathrm{T})$ and their interactions on gill stress enzymes activity in $P$. major 


\section{Transcriptional profiling}

Interleukin $8 \quad(I L 8, \quad H M 453864.1), \quad$ Interleukin-1 $\beta \quad\left(I L^{-1} \beta\right.$, AY257219.1), Major Histocompatibilty Complex IIA (MHCIIA, AY698064.1), Tumor Necrosis Factor a (TNF $\alpha$, AY314010.1), Hepcidin 1 (AY452732.1), Hepcidin 2 (AY669383.1), Transferrin (AY335444.1), Natural resistance-associated macrophage protein (NRAMP, AY485311.1) and ribosomal protein L8 (internal control, AY190734.1) sequences were obtained from National Center for Biotechnology Information (NCBI). All these genes were initially PCR amplified from liver cDNA (prepared by superscript III, Invitrogen, USA) using gene specific primer (Supplementary Table 1) and cloned into pGEMTeasy vector. One positive clone of each gene was used to prepare the Realtime PCR standard.

RNAs were isolated from the samples stored in RNAlater using Quazol (Quigen, USA), following manufacturer's protocol. gDNA eliminator solution was used to remove the genomic DNA contaminations. After quantification of RNA, $1 \mu \mathrm{g}$ RNA of each sample was used to prepare the cDNA using superscript III vaio kit (Invitrogen, USA) and then diluted to a final volume of $100 \mu \mathrm{L} .1 \mu \mathrm{L}$ of prepared cDNA was used for Real-time PCR analysis of each gene. The Real-time PCR conditions included initial denaturation at $94^{\circ} \mathrm{C}(2 \mathrm{~min})$ followed by 40 cycles of $94^{\circ} \mathrm{C}(30 \mathrm{~s})$ and $60^{\circ} \mathrm{C}(1 \mathrm{~min})$. Relative expression was calculated using L8 expression (internal control). PCR was performed on a Geneamp PCR system 9700 thermal cycler (Applied Biosystem, USA), using gene specific primers (Supplementary Table 1).

\section{Histological analysis}

The gills of the sampled fish were dissected free from the head and fixed in Bouin solution for $24 \mathrm{~h}$ at $4^{\circ} \mathrm{C}$ and then preserved in $70 \%$ ethanol and stored at $4^{\circ} \mathrm{C}$ until further use [19]. Later the samples were dehydrated (using a series of $70 \%, 90 \%$ and $100 \%$ ethanol), cleared in lemosol and embedded in paraffin. These were sectioned $(4 \mu \mathrm{m})$ using a Leica RM2255 microtome (Leica Microsystems, Germany), mounted onto SuperFrost MAS-coated glass slides (Matsunami, Japan) and dried at $37^{\circ} \mathrm{C}$ for $24 \mathrm{~h}$. The sections were stained with Mallory-Heidenhain's Azan staining method [20] with slight modifications. Briefly, sections were deparaffinized with xylene, rehydrated using graded ethanol, re-fixed in mordant solution, and serially stained with Azocarmine G. Excess stain was removed by Aniline-ethanol and Acetic-ethanol wash. Further, the slides were re-incubated with 5\% Phosphotungstic acid hydrate solution, stained with Aniline blue-Orange G solution, dehydrated with ethanol $(100 \%)$ and mounted in mixed solution of Canada balsam and xylene.

\section{Two-colored immunohistochemistry (IHC)}

The fixed and paraffin embedded gill samples were sectioned $(10 \mu \mathrm{m}$ thickness), deparaffinized,rehydrated and processed using previously published protocols [21]. The tissue fragments were then blocked in $2 \%$ blocking solution (Roche, Germany), incubated overnight at $4^{\circ} \mathrm{C}$ with Annexin V-Alexa 488 (Invitrogen, USA) and Beclin1-Alexa 561 (Abgent, USA) antibodies (both 1:500 dilution). Annexin V and Beclin1 antibodies, respectively, are known to depict strong signals in the apoptotic and autophagic cells of red sea bream. The antibodycoupled gill sections were then rinsed with PBST (PBS with $0.01 \%$ Tween 20), and analyzed or photographed using Confocal microscope (LSM 710, Zeiss, Germany).

\section{Survivability}

The fish health was monitored on a daily basis, using mobility, swimming behavior, body color, scale erosions, morbidity and food intake as principle wellbeing status criteria. Mortality was observed for all the groups for the entire experimental period. The mortality aspects were approved by the Animal Ethics and Use Committee of Ehime University, Japan. Sampling of the surviving fish was humanely (mentioned above) carried out at 0,5 and 10 dai. Survivability was calculated using the following formula:

$\%$ Survivability $=\left[\begin{array}{l}\text { Total number of remaining fish at previous } \\ \text { sampling point }- \text { total number of fish died } \\ \text { between two sampling points }\end{array}\right] \times 100 /$ Total number of remaining fish at previous sampling point

Note that for 0 dai, the initial stocked number of fish was used for calculating the $\%$ survivability.

\section{Disease resistance index (DRI)}

An overall DRI was calculated using the following formula:

$$
D R I=\frac{1}{n} \sum_{i=1}^{n} \frac{\left|X_{i}-X_{r e f}\right|}{\operatorname{Max}\left\{\left|X_{i}-X_{i} f_{i}\right|\right\}} * 100
$$

Where $\mathrm{Xi}$ is the value of the $\mathrm{i}^{\text {th }}$ variable.

Xrefi is the reference value of the variable $i$ which indicates its measurement at a healthy state.

The reference value indicating a healthy state differs from one variable to another according to the direction of variation depending on our preliminary analysis and available literatures, i.e. lower value indicates healthy state for some variables, such as the bacterial count, and higher value for other variables, such as the survivability rate. Thus, taking into consideration the two directions forcalculating the DRI, the Xrefi was considered as the maximum values, Max $\{x i\}$ for the first group of variables and the minimum value $\operatorname{Min}\{x i\}$ for the second group.

Thus, each variable that entered the DRI was normalized to be between 0 and 100 and the DRI is interpreted as follow: The more the index, the better the overall resistance disease and vice versa.

\section{Statistical analysis}

One-way or Three-way analysis of variance (ANOVA) and Tukey's test was used for data analysis and significance calculation between the treatment means, respectively, using SPSS (Statistical Package for Social Sciences, Version 22.0) software. All experimental data are depicted as the mean \pm SE. Differences were considered statistically significant at $\mathrm{P}<0.05$, if not otherwise mentioned.

\section{Results}

\section{E. tarda population and iron regulatory genes expression}

The highest amount of relative E. tarda content was noticed at 0 dai in spleen and muscle of both the starved-infected and fedinfected groups (Figure 1). Although gradual decrease in the bacterial population was observed in both the tissues of the fed-infected group at 5 dai onwards, nearly no bacterial count was observed in the starvedinfected groups at both 5 and 10 dai.

In spleen, the genes regulating the iron homeostasis, viz., Hepcidin 1, Hepcidin 2, Transferrin and NRAMP, showed a similar starvation related alteration (Figure 2). At 0 dai, the starved group showed a significant $(\mathrm{P}<0.05)$ increase in the expression of all the four studied genes, which however reduced drastically from 5 dai onwards. No significant $(\mathrm{P}>0.05)$ difference in expression pattern was observed between the infected and non-infected groups in the studied genes. 
A

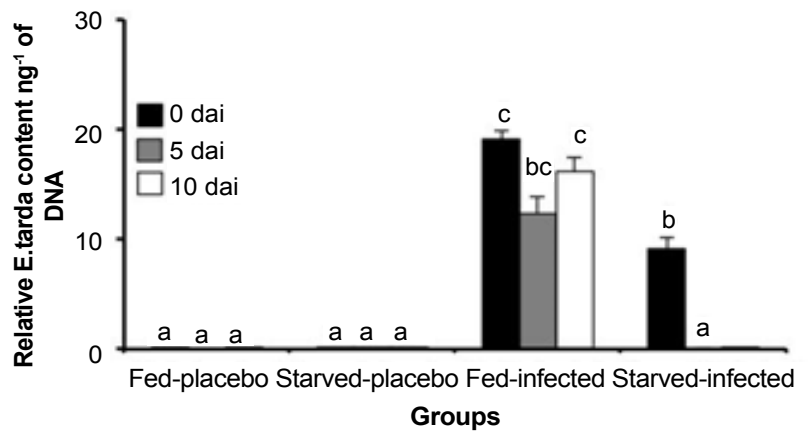

B

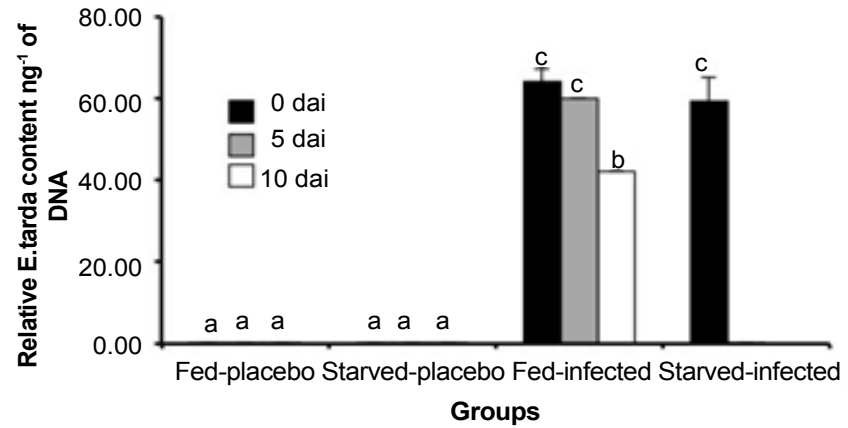

Figure 1: Real-time analysis of bacterial load in spleen (A) and muscle (B) of different experimental group. Data are shown as the mean \pm S.E., and expressed as relative $E$. tarda content per ng DNA. Letters above the bars indicate that these groups differ significantly from each other at $P<0.05$.

A

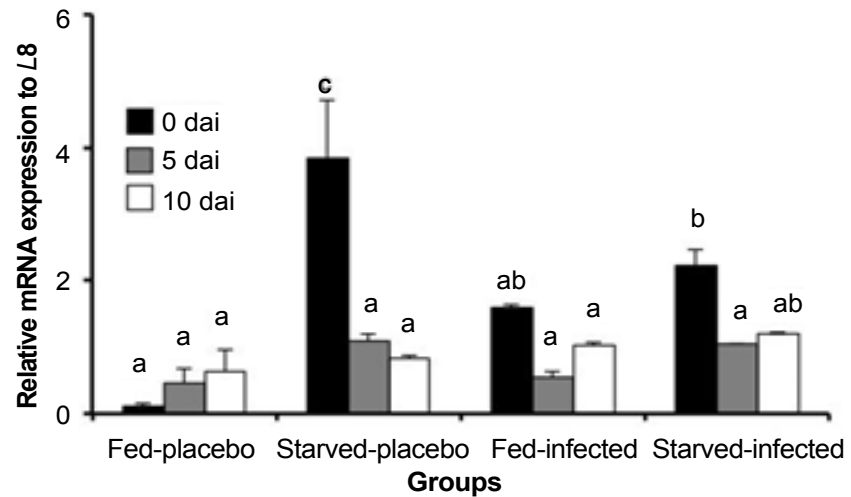

C

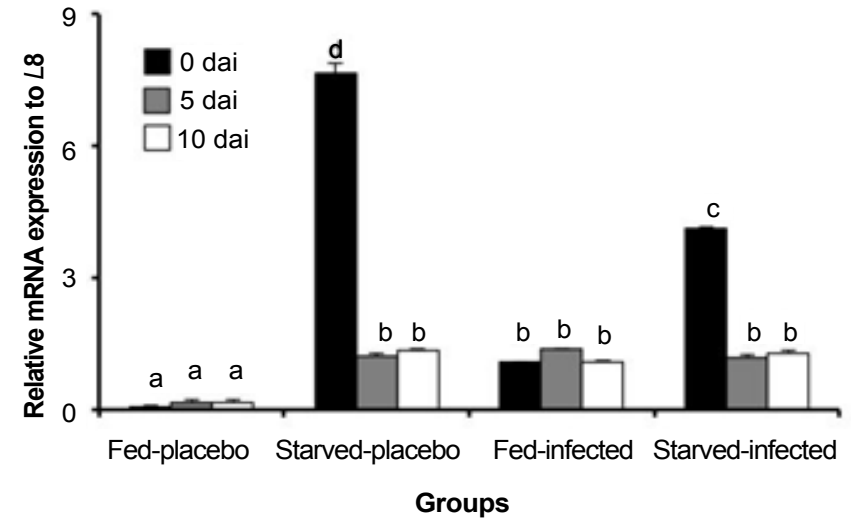

B

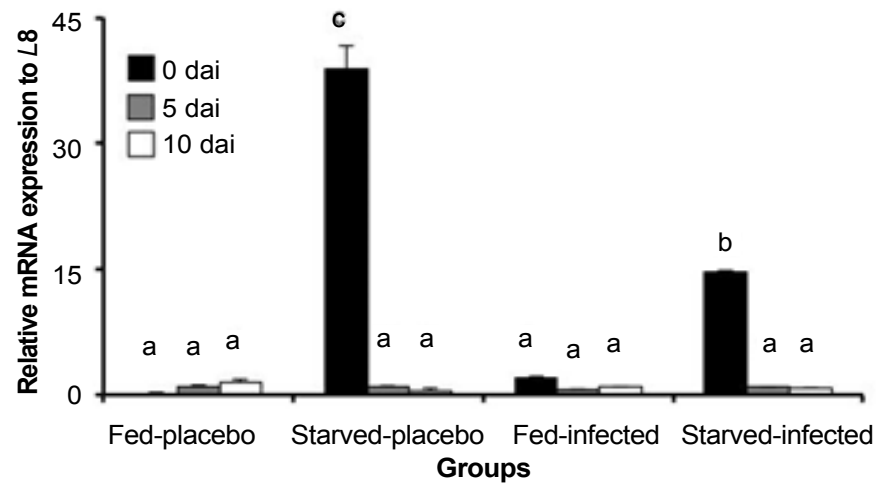

D

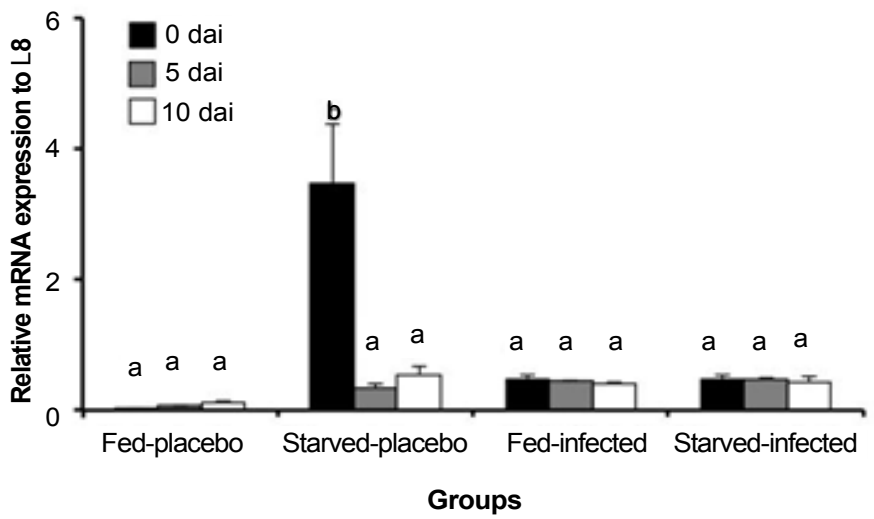

Figure 2: mRNA expression analysis of metal ion binding proteins by Real-time PCR. Changes in mRNA levels of Hepcidin1 (A), Hepcidin2 (B), Transferrin (C) and NRAMP (D) are plotted on Y-axis against different experimental groups. Data are shown as the mean \pm SE, and expressed as relative abundance corrected for L8. Letters above the bars indicate that these groups differ significantly from each other at $P<0.05$.

\section{Gill morphology, mucus production and oxidative stress response}

Mucus, produced by mucus producing cells, is one of the first hand defence mechanism in fish. In order to find out the effect of starvation and infection on mucus production, we analysed the gill fragments by Azan staining (Figure 3). We found that, in comparison to fedplacebo group (Figures $3 \mathrm{~A}$ and $3 \mathrm{E}$ ), starved-placebo group showed severe hyperplasia of mucus producing cells (Figure 4). In fact, the mucus production was also enhanced in the gills of starved-placebo fish (Figures 3B and 3F). As expected, fed-infected group (Figures 3C 
Citation: Mohapatra S, Chakraborty T, Kacem RH, Shimizu S, Matsubara T, et al. (2016) Starvation: An Alternate Measure to Improve Immunity and Physiology of Red Sea Bream During Edwardsiella Tarda Infection. J Aquac Res Development S2: 007. doi:10.4172/2155-9546.S2-007

Page 5 of 12

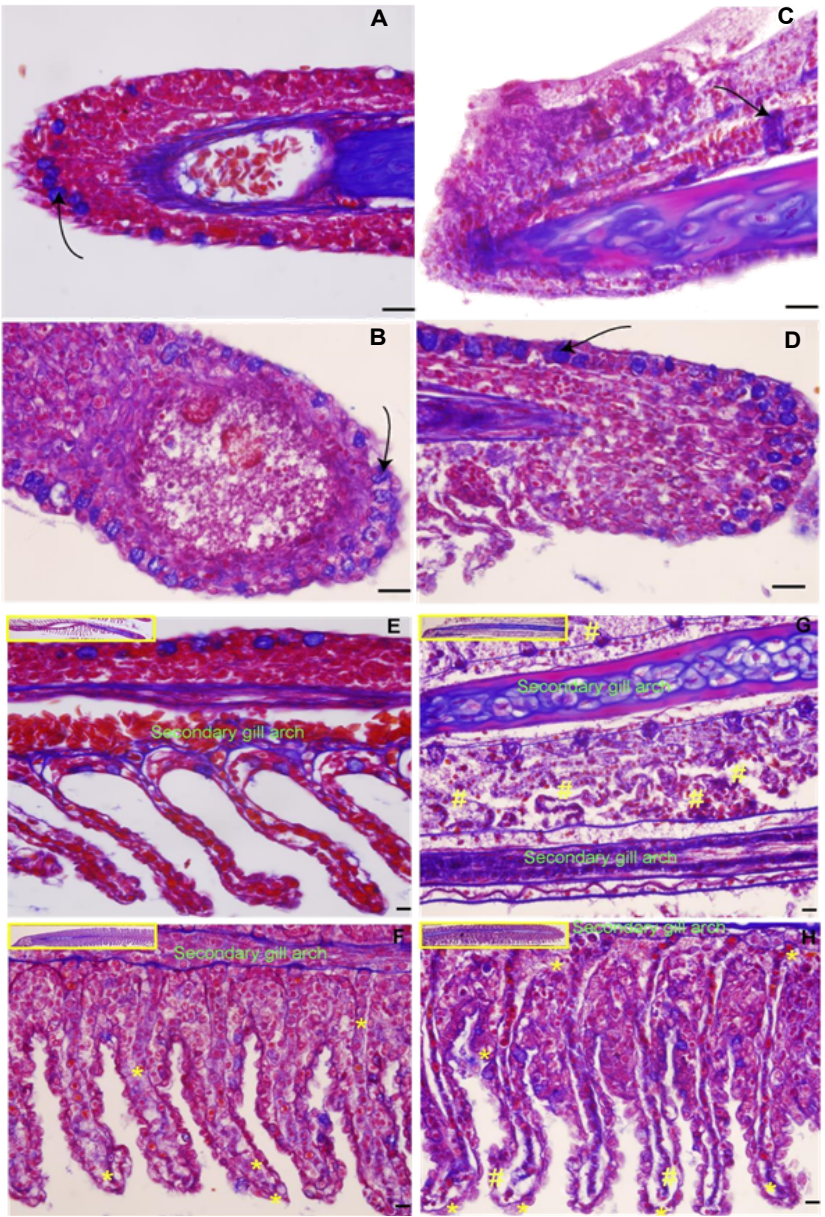

Figure 3: Effects of starvation and E. tarda infection on gill morphology and mucus production at 10 dai. Distribution of mucus producing cells in the tip of primary gill lamellae $(A-D)$ and Assessment of secondary gill degradation $(E-$ $H$ ) were determined by Azan staining, where $A \& E, B \& F, C$ \& $G$, and $D \& H$ represents Fed-placebo, Starved-placebo, Fed-infected and Starved-infected groups, respectively. Note: Black arrow denotes representative mucus cells; while asterisks are given for representative degradation patterns. "\#" shows severe degradation (disintegration of blood vessels and detachment of secondary gill lamellae from secondary gill arch) and "*" represents slight degradation (slight disruptions of blood vessels, breakage of the tips of the secondary gill lamellae). Mucus cell hyperplasia is observed in the starved groups as compared to the fed groups. Blue and orange color indicates the mucus and blood cells, respectively. Scale bar length - $20 \mu \mathrm{m}$. Inset Representative primary gill lamellae.

and 3G) showed excessive mucus production and increased blood flow along with excessive primary and secondary lamellar degradation, at 10 dai. However, after infection, the starved fish showed slight increase in mucus production than their non-infected counterpart (Figures 3D and $3 \mathrm{H})$.

Both the gill SOD and CAT showed significant $(\mathrm{P}<0.05)$ difference between the infected and the non-infected groups, as well as between the different time points (Table 1). Higher values of gill SOD was observed in the fed-infected group than the starved-infected group.

\section{Blood glucose and hemoglobin production}

Blood glucose is a major indicator of any kind of changes in the body. In our study, blood glucose level showed no significant $(P>0.05)$ increase after starvation at 0 and 5 dai, however reduced drastically in the 10 dai starved fish (Figure 5A). In both infected groups, decreased glucose level, in comparison to placebo groups, was observed at 0 dai, which peaked at 5 dai, and again reduced at 10 dai.

On the other hand, haemoglobin $(\mathrm{Hb})$ production remained unaltered in the starved-placebo group in relation to the fed-placebo fish. However, infection reduced the $\mathrm{Hb}$ content significantly $(\mathrm{P}<0.05)$ in the fed-infected group (Figure $5 \mathrm{~B})$. Amongst the fed-infected and starved-infected groups, the latter had higher $\mathrm{Hb}$ values.

\section{Effects on phagocytosis}

At 0 dai, the starved-placebo fish showed increased NBT values, which however reduceddrastically after infection (Figure 5C). On the other hand, after infection, fed fish showed significant $(\mathrm{P}<0.05)$ difference in phagocytosis in comparison to the fed-placebo fish. However, we did not observe any significant $(\mathrm{P}>0.05)$ difference in NBT activity after infection in both the fed and starved group, except at 0 dai.

\section{Serum profiling}

No significant $(\mathrm{P}>0.05)$ decrease in the serum protein and globulin was observed in the starved- placebo group in comparison to the fedplacebo group (Table 2). Although the total serum protein decreased further after infection, the fed-infected group should a greater reduction than the starved- infected group. Even though albumin levels increased after infection, starvation alone was unable to change the albumin profile in red sea bream (Table 2). Similarly, the infected groups had higher A:G value than the placebo groups (Table 2).

\section{Serum anti-oxidation characteristics}

SOD and CAT activities were found to be highest in the fedinfected group followed by the starved-infected group (Table 3). The maximum difference in the activities of both the enzymes was noticed among the fed-infected and starved-infected groups at 0 dai. Although, starvation and infection had significant $(\mathrm{P}<0.05)$ effect on the SOD level, the CAT level remained non-significant $(\mathrm{P}>0.05)$ to starvation. Similarly, the GPX activity was highest in the fed-infected group, but

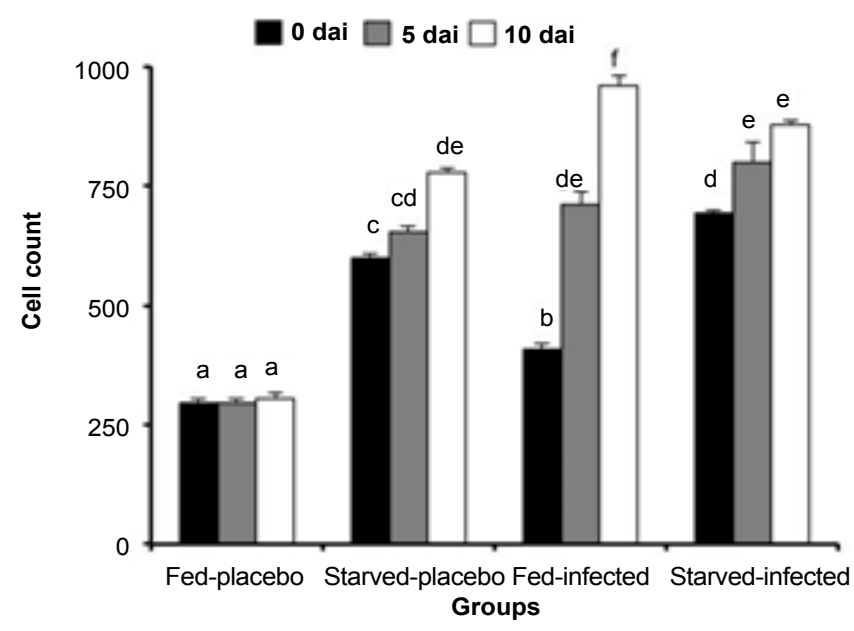

Figure 4: Analysis of the mucus-producing cell hyperplasia. The average numbers of mucus producing cells in eight randomly selected gill filaments were plotted to evaluate the mucus-producing cell proliferation potential and hence mucus production capacity of different experimental groups. Data are shown as the mean $\pm \mathrm{SE}$, and letters above the bars indicate that these groups differ significantly from each other at $P<0.05$. 
Citation: Mohapatra S, Chakraborty T, Kacem RH, Shimizu S, Matsubara T, et al. (2016) Starvation: An Alternate Measure to Improve Immunity and Physiology of Red Sea Bream During Edwardsiella Tarda Infection. J Aquac Res Development S2: 007. doi:10.4172/2155-9546.S2-007

A
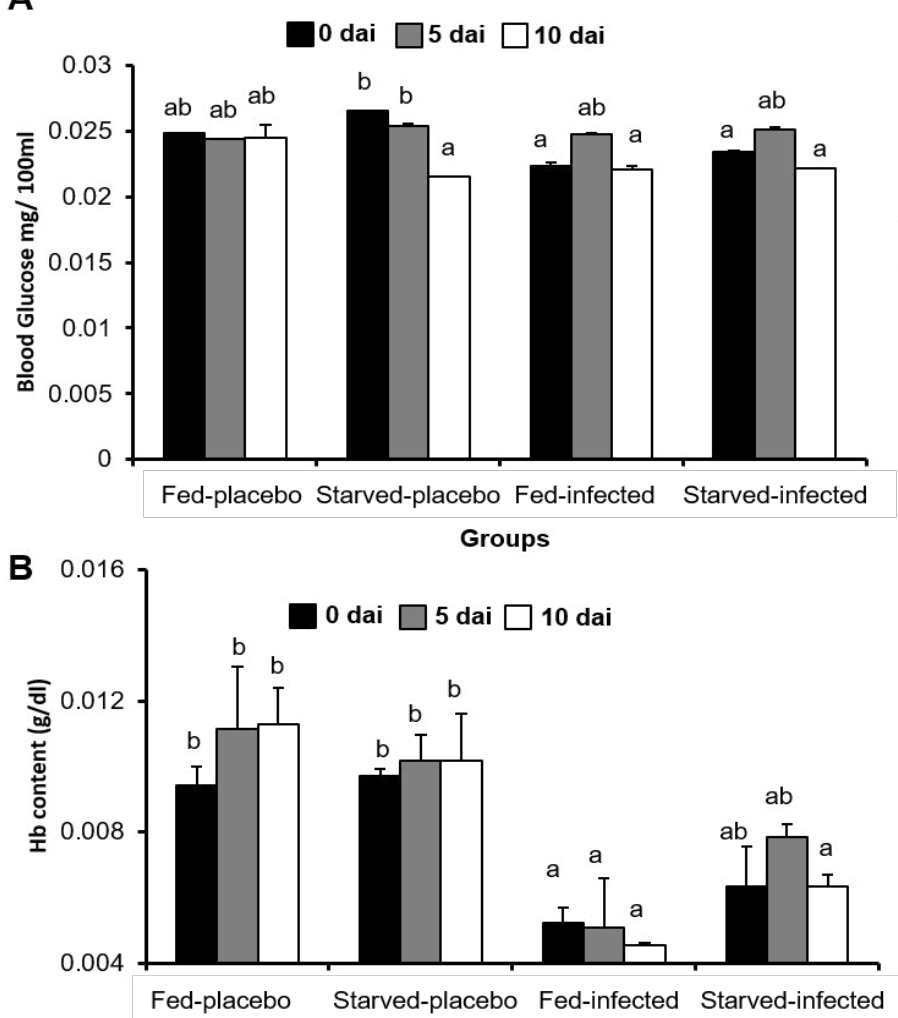

C

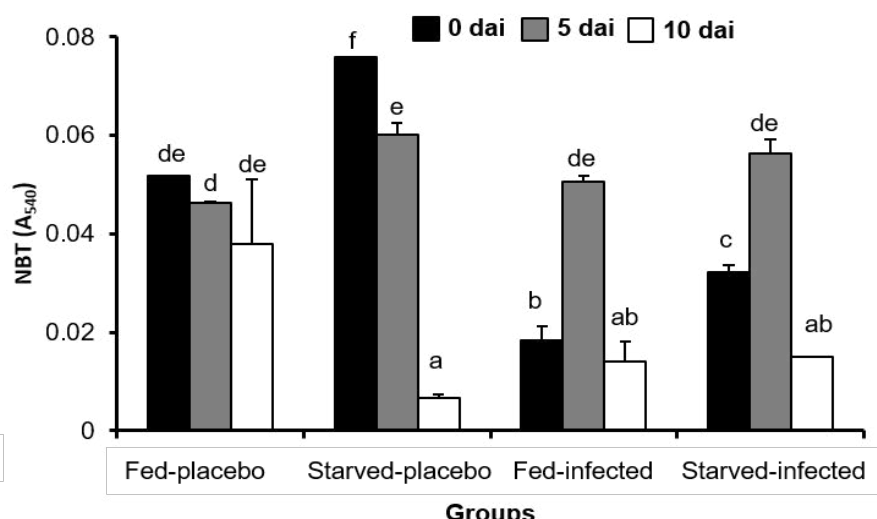

Figure 5: Biochemical analysis of blood samples from different groups. Blood glucose (A), Hemoglobin content (B) and Respiratory burst activity (NBT) (C) were measured. Data are shown as the mean $\pm \mathrm{SE}$, and letters above the bars indicate that these groups differ significantly from each other at $P<0.05$.

\begin{tabular}{|c|c|c|c|c|c|c|c|c|c|c|c|c|c|c|c|c|c|}
\hline \multirow{2}{*}{ Parameters } & & \multicolumn{3}{|c|}{ Placebo } & \multirow{2}{*}{$\begin{array}{c}\text { Mean } \\
\text { Placebo }\end{array}$} & \multicolumn{3}{|c|}{ Infected } & \multirow{2}{*}{$\begin{array}{c}\text { Mean } \\
\text { Infected }\end{array}$} & \multirow{2}{*}{$\begin{array}{l}\text { Overall } \\
\text { Mean }\end{array}$} & \multicolumn{7}{|c|}{$\begin{array}{c}\text { Significance }(P<0.05) \text { by three way } \\
\text { ANOVA }\end{array}$} \\
\hline & & T0 & T5 & T10 & & T0 & T5 & T10 & & & St & $T$ & 1 & StT & Stl & TI & StTI \\
\hline \multirow{3}{*}{$\begin{array}{l}\text { Serum } \\
\text { protein }\end{array}$} & Fed & $\begin{array}{l}0.75 \pm \\
0.01^{d}\end{array}$ & $\begin{array}{l}0.53 \pm \\
0.02^{\mathrm{abc}}\end{array}$ & $\begin{array}{l}0.77 \pm \\
0.04^{\mathrm{abcd}}\end{array}$ & $\begin{array}{l}0.68 \pm \\
0.02^{\mathrm{B}}\end{array}$ & $\begin{array}{l}0.39 \pm \\
0.11^{\mathrm{a}}\end{array}$ & $\begin{array}{l}0.66 \pm \\
0.04^{\text {bcd }}\end{array}$ & $\begin{array}{l}0.51 \pm \\
0.00^{\mathrm{ab}}\end{array}$ & $\begin{array}{l}0.52 \pm \\
0.04^{\mathrm{A}}\end{array}$ & $\begin{array}{c}0.60 \pm \\
0.03\end{array}$ & \multirow{3}{*}{ NS } & \multirow{3}{*}{$S$} & \multirow{3}{*}{$S$} & \multirow{3}{*}{ NS } & \multirow{3}{*}{ NS } & \multirow{3}{*}{ S } & \multirow{3}{*}{$S$} \\
\hline & Starved & $\begin{array}{l}0.60 \pm \\
0.04^{\mathrm{dc}}\end{array}$ & $\begin{array}{l}0.64 \pm \\
0.01^{\mathrm{abcd}}\end{array}$ & $\begin{array}{l}0.68 \pm \\
0.04^{\mathrm{abc}}\end{array}$ & $\begin{array}{l}0.64 \pm \\
0.02^{\mathrm{B}}\end{array}$ & $\begin{array}{l}0.44 \pm \\
0.07^{\mathrm{abcd}}\end{array}$ & $\begin{array}{l}0.62 \pm \\
0.04^{\mathrm{abc}}\end{array}$ & $\begin{array}{l}0.64 \pm \\
0.06\end{array}$ & $\begin{array}{l}0.57 \pm \\
0.04^{\mathrm{AB}}\end{array}$ & $\begin{array}{l}0.60 \pm \\
0.02\end{array}$ & & & & & & & \\
\hline & Mean & $\begin{array}{c}0.67 \pm \\
0.02\end{array}$ & $\begin{array}{l}0.59 \pm \\
0.02\end{array}$ & $\begin{array}{l}0.73 \pm \\
0.03\end{array}$ & $\begin{array}{l}0.66 \pm \\
0.02^{N}\end{array}$ & $\begin{array}{l}0.42 \pm \\
0.07\end{array}$ & $\begin{array}{l}0.64 \pm \\
0.03\end{array}$ & $\begin{array}{l}0.57 \pm \\
0.03\end{array}$ & $\begin{array}{l}0.54 \pm \\
0.03^{\mathrm{M}}\end{array}$ & & & & & & & & \\
\hline \multirow{3}{*}{ Albumin } & Fed & $\begin{array}{l}0.01 \pm \\
0.00^{\mathrm{a}}\end{array}$ & $\begin{array}{l}0.01 \pm \\
0.00^{\mathrm{a}}\end{array}$ & $\begin{array}{l}0.01 \pm \\
0.00^{\mathrm{a}}\end{array}$ & $\begin{array}{l}0.01 \pm \\
0.00^{\mathrm{AB}}\end{array}$ & $\begin{array}{l}0.05 \pm \\
0.02^{\mathrm{b}}\end{array}$ & $\begin{array}{l}0.03 \pm \\
0.01^{b}\end{array}$ & $\begin{array}{l}0.01 \pm \\
0.00^{\mathrm{b}}\end{array}$ & $\begin{array}{l}0.03 \pm \\
0.01^{\mathrm{B}}\end{array}$ & $\begin{array}{c}0.02 \pm \\
0.00\end{array}$ & \multirow{3}{*}{ NS } & \multirow{3}{*}{$\mathrm{S}$} & \multirow{3}{*}{ S } & \multirow{3}{*}{ NS } & \multirow{3}{*}{ NS } & \multirow{3}{*}{ S } & \multirow{3}{*}{ NS } \\
\hline & Starved & $\begin{array}{l}0.02 \pm \\
0.00^{\mathrm{ab}}\end{array}$ & $\begin{array}{c}0.01 \pm \\
0.00^{\mathrm{a}}\end{array}$ & $\begin{array}{c}0.01 \pm \\
0.00^{\mathrm{a}}\end{array}$ & $\begin{array}{c}0.01 \pm \\
0.00^{A}\end{array}$ & $\begin{array}{l}0.06 \pm \\
0.03^{\text {ab }}\end{array}$ & $\begin{array}{c}0.03 \pm \\
0.01^{\mathrm{b}}\end{array}$ & $\begin{array}{l}0.01 \pm \\
0.00^{\mathrm{ab}}\end{array}$ & $\begin{array}{c}0.03 \pm \\
0.01^{\mathrm{B}}\end{array}$ & $\begin{array}{c}0.02 \pm \\
0.00\end{array}$ & & & & & & & \\
\hline & Mean & $\begin{array}{c}0.02 \pm \\
0.00\end{array}$ & $\begin{array}{c}0.01 \pm \\
0.00\end{array}$ & $\begin{array}{c}0.01 \pm \\
0.00\end{array}$ & $\begin{array}{l}0.01 \pm \\
0.00^{N}\end{array}$ & $\begin{array}{c}0.06 \pm \\
0.02\end{array}$ & $\begin{array}{c}0.03 \pm \\
0.01\end{array}$ & $\begin{array}{c}0.01 \pm \\
0.00\end{array}$ & $\begin{array}{l}0.03 \pm \\
0.01^{\mathrm{M}}\end{array}$ & & & & & & & & \\
\hline \multirow{3}{*}{ Globulin } & Fed & $\begin{array}{c}0.73 \pm \\
0.01^{\mathrm{d}}\end{array}$ & $\begin{array}{l}0.52 \pm \\
0.02^{\mathrm{abc}}\end{array}$ & $\begin{array}{l}0.76 \pm \\
0.04^{\text {abc }}\end{array}$ & $\begin{array}{c}0.67 \pm \\
0.02^{\mathrm{B}}\end{array}$ & $\begin{array}{c}0.34 \pm \\
0.11^{\mathrm{a}}\end{array}$ & $\begin{array}{l}0.64 \pm \\
0.04^{\text {bcd }}\end{array}$ & $\begin{array}{l}0.50 \pm \\
0.00^{\mathrm{abc}}\end{array}$ & $\begin{array}{c}0.49 \pm \\
0.04^{\mathrm{A}}\end{array}$ & $\begin{array}{c}0.58 \pm \\
0.03\end{array}$ & \multirow{3}{*}{ NS } & \multirow{3}{*}{$\mathrm{S}$} & \multirow{3}{*}{$S$} & \multirow{3}{*}{ NS } & \multirow{3}{*}{ NS } & \multirow{3}{*}{ S } & \multirow{3}{*}{$\mathrm{S}$} \\
\hline & Starved & $\begin{array}{l}0.58 \pm \\
0.04^{\text {cd }}\end{array}$ & $\begin{array}{l}0.63 \pm \\
0.01^{\mathrm{ab}}\end{array}$ & $\begin{array}{l}0.67 \pm \\
0.04^{\mathrm{ab}}\end{array}$ & $\begin{array}{c}0.63 \pm \\
0.02^{\mathrm{B}}\end{array}$ & $\begin{array}{c}0.38 \pm \\
0.05^{\mathrm{a}}\end{array}$ & $\begin{array}{l}0.59 \pm \\
0.04^{\mathrm{abc}}\end{array}$ & $\begin{array}{l}0.63 \pm \\
0.06^{\mathrm{abc}}\end{array}$ & $\begin{array}{l}0.53 \pm \\
0.03^{\mathrm{A}}\end{array}$ & $\begin{array}{c}0.58 \pm \\
0.02\end{array}$ & & & & & & & \\
\hline & Mean & $\begin{array}{c}0.66 \pm \\
0.02\end{array}$ & $\begin{array}{c}0.57 \pm \\
0.02\end{array}$ & $\begin{array}{c}0.72 \pm \\
0.03\end{array}$ & $\begin{array}{l}0.65 \pm \\
0.02^{N}\end{array}$ & $\begin{array}{c}0.36 \pm \\
0.06\end{array}$ & $\begin{array}{c}0.62 \pm \\
0.03\end{array}$ & $\begin{array}{c}0.57 \pm \\
0.03\end{array}$ & $\begin{array}{l}0.51 \pm \\
0.03^{\mathrm{M}}\end{array}$ & & & & & & & & \\
\hline \multirow[t]{3}{*}{$A: G$} & Fed & $\begin{array}{c}0.02 \pm \\
0.00^{\mathrm{a}}\end{array}$ & $\begin{array}{l}0.03 \pm \\
0.00^{\mathrm{ab}}\end{array}$ & $\begin{array}{c}0.01 \pm \\
0.00^{\mathrm{a}}\end{array}$ & $\begin{array}{c}0.02 \pm \\
0.00^{A}\end{array}$ & $\begin{array}{c}0.19 \pm \\
0.06^{c}\end{array}$ & $\begin{array}{l}0.05 \pm \\
0.01^{\mathrm{ab}}\end{array}$ & $\begin{array}{c}0.01 \pm \\
0.00^{\mathrm{a}}\end{array}$ & $\begin{array}{l}0.08 \pm \\
0.02^{\mathrm{B}}\end{array}$ & $\begin{array}{c}0.05 \pm \\
0.01\end{array}$ & \multirow{3}{*}{ NS } & & & & & & \\
\hline & Starved & $\begin{array}{l}0.03 \pm \\
0.01^{\mathrm{ab}}\end{array}$ & $\begin{array}{c}0.01 \pm \\
0.00^{\mathrm{a}}\end{array}$ & $\begin{array}{c}0.02 \pm \\
0.00^{\mathrm{a}}\end{array}$ & $\begin{array}{c}0.02 \pm \\
0.00^{A}\end{array}$ & $\begin{array}{c}0.13 \pm \\
0.04^{\circ}\end{array}$ & $\begin{array}{l}0.05 \pm \\
0.02^{\mathrm{ab}}\end{array}$ & $\begin{array}{c}0.02 \pm \\
0.00^{\mathrm{a}}\end{array}$ & $\begin{array}{c}0.07 \pm \\
0.02^{\mathrm{B}}\end{array}$ & $\begin{array}{c}0.04 \pm \\
0.01\end{array}$ & & $\mathrm{~S}$ & S & NS & NS & S & NS \\
\hline & Mean & $\begin{array}{c}0.02 \pm \\
0.00\end{array}$ & $\begin{array}{c}0.02 \pm \\
0.00\end{array}$ & $\begin{array}{c}0.02 \pm \\
0.00\end{array}$ & $\begin{array}{l}0.02 \pm \\
0.00^{N}\end{array}$ & $\begin{array}{c}0.16 \pm \\
0.04\end{array}$ & $\begin{array}{c}0.05 \pm \\
0.01\end{array}$ & $\begin{array}{c}0.01 \pm \\
0.00\end{array}$ & $\begin{array}{l}0.07 \pm \\
0.01^{\mathrm{M}}\end{array}$ & & & & & & & & \\
\hline
\end{tabular}

Data expressed as mean \pm SE $(n=4)$. All significance are measured at $P<0.05$. Different small superscript $(a, b, c, d$, etc.) represent the level of significance among different treatment groups at different sampling points for a particular parameter. Different capital superscript $(A, B, C)$ represents significant difference between means of different experimental groups (fed-placebo, starved-placebo, fed-infected and starved-infected groups). Overall mean value having different capital superscript ( $\mathrm{M} \& \mathrm{~N}, \mathrm{X}$ \& Y) vary significantly. S-Significant, NS-Non-significant. Units: Serum protein $-\mathrm{mg} \mathrm{ml}^{-1}$; Albumin $-\mathrm{mg} \mathrm{ml}^{-1}$; Globulin $-\mathrm{mg} \mathrm{ml}$

Table 2: Effect of starvation (St), E. tarda infection (I), treatment time (T) and their interactions on serum protein profile in $P$. major. 
Citation: Mohapatra S, Chakraborty T, Kacem RH, Shimizu S, Matsubara T, et al. (2016) Starvation: An Alternate Measure to Improve Immunity and Physiology of Red Sea Bream During Edwardsiella Tarda Infection. J Aquac Res Development S2: 007. doi:10.4172/2155-9546.S2-007

Page 7 of 12

\begin{tabular}{|c|c|c|c|c|c|c|c|c|c|c|c|c|c|c|c|c|c|}
\hline \multirow[t]{2}{*}{ Parameters } & & \multicolumn{3}{|c|}{ Placebo } & \multirow{2}{*}{$\begin{array}{c}\text { Mean } \\
\text { Placebo }\end{array}$} & \multicolumn{3}{|c|}{ Infected } & \multirow{2}{*}{$\begin{array}{c}\text { Mean } \\
\text { Infected }\end{array}$} & \multirow{2}{*}{$\begin{array}{l}\text { Overall } \\
\text { Mean }\end{array}$} & \multicolumn{7}{|c|}{$\begin{array}{c}\text { Significance }(P<0.05) \text { by three way } \\
\text { ANOVA }\end{array}$} \\
\hline & & T0 & T5 & $\mathrm{T} 10$ & & T0 & T5 & $\mathrm{T} 10$ & & & St & $\mathrm{T}$ & 1 & StT & Stl & TI & StTI \\
\hline \multirow{3}{*}{ SOD } & Fed & $\begin{array}{l}1.79 \pm \\
0.18^{\mathrm{a}}\end{array}$ & $\begin{array}{l}2.96 \pm \\
0.30^{\mathrm{ab}}\end{array}$ & $\begin{array}{l}1.71 \pm \\
0.10^{\mathrm{a}}\end{array}$ & $\begin{array}{l}2.15 \pm \\
0.15^{\mathrm{A}}\end{array}$ & $\begin{array}{r}23.70 \pm \\
6.81^{\mathrm{d}}\end{array}$ & $\begin{array}{l}2.07 \pm \\
0.26^{\mathrm{ab}}\end{array}$ & $\begin{array}{l}2.44 \pm \\
0.00^{\mathrm{ab}}\end{array}$ & $\begin{array}{l}9.40 \pm \\
2.79^{c}\end{array}$ & $\begin{array}{l}5.78 \pm \\
1.45^{Y}\end{array}$ & \multirow{3}{*}{$\mathrm{S}$} & \multirow{3}{*}{$\mathrm{S}$} & \multirow{3}{*}{$S$} & \multirow{3}{*}{$\mathrm{S}$} & \multirow{3}{*}{$S$} & \multirow{3}{*}{$\mathrm{S}$} & \multirow{3}{*}{$S$} \\
\hline & Starved & $\begin{array}{l}1.97 \pm \\
0.48^{\mathrm{a}}\end{array}$ & $\begin{array}{l}2.79 \pm \\
0.06^{\mathrm{ab}}\end{array}$ & $\begin{array}{l}2.15 \pm \\
0.37^{\mathrm{ab}}\end{array}$ & $\begin{array}{l}2.31 \pm \\
0.21^{\mathrm{AB}}\end{array}$ & $\begin{array}{r}6.70 \pm \\
1.08^{\mathrm{c}}\end{array}$ & $\begin{array}{l}2.29 \pm \\
0.37^{\mathrm{ab}}\end{array}$ & $\begin{array}{c}0.690 \pm \\
05^{\mathrm{a}}\end{array}$ & $\begin{array}{l}3.23 \pm \\
0.57^{\mathrm{B}}\end{array}$ & $\begin{array}{l}2.77 \pm \\
0.30^{x}\end{array}$ & & & & & & & \\
\hline & Mean & $\begin{array}{l}1.88 \pm \\
0.25\end{array}$ & $\begin{array}{l}2.88 \pm \\
0.15\end{array}$ & $\begin{array}{c}1.93 \pm \\
0.19\end{array}$ & $\begin{array}{l}2.23 \pm \\
0.13^{\mathrm{M}}\end{array}$ & $\begin{array}{c}15.20 \pm \\
3.81\end{array}$ & $\begin{array}{c}2.18 \pm \\
0.22\end{array}$ & $\begin{array}{l}1.56 \pm \\
0.18\end{array}$ & $\begin{array}{l}6.31 \pm \\
1.46^{N}\end{array}$ & & & & & & & & \\
\hline \multirow{3}{*}{ CAT } & Fed & $\begin{array}{c}194.84 \pm \\
20.2^{\mathrm{ab}}\end{array}$ & $\begin{array}{c}107.38 \pm \\
8.76^{\mathrm{a}}\end{array}$ & $\begin{array}{c}96.52 \pm \\
12.85^{\mathrm{a}}\end{array}$ & $\begin{array}{c}132.91 \pm \\
11.11^{\mathrm{A}}\end{array}$ & $\begin{array}{l}847.21 \pm \\
316.84^{d}\end{array}$ & $\begin{array}{c}106.13 \pm \\
11.13^{\mathrm{a}}\end{array}$ & $\begin{array}{c}217.92 \pm \\
0.00^{\mathrm{a}}\end{array}$ & $\begin{array}{l}390.4 \pm \\
116.49^{\mathrm{B}}\end{array}$ & $\begin{array}{c}261.66 \pm \\
60.07\end{array}$ & \multirow{3}{*}{ NS } & \multirow{3}{*}{$\mathrm{S}$} & \multirow{3}{*}{$S$} & \multirow{3}{*}{$\mathrm{S}$} & \multirow{3}{*}{$S$} & \multirow{3}{*}{$\mathrm{S}$} & \multirow{3}{*}{ NS } \\
\hline & Starved & $\begin{array}{c}292.62 \pm \\
45.0^{\mathrm{abc}}\end{array}$ & $\begin{array}{c}221.05 \pm \\
21.5^{\mathrm{bc}}\end{array}$ & $\begin{array}{c}232.09 \pm \\
32.72^{\text {bc }}\end{array}$ & $\begin{array}{c}248.59 \pm \\
20.02^{\mathrm{B}}\end{array}$ & $\begin{array}{c}342.39 \pm \\
29.45^{c}\end{array}$ & $\begin{array}{c}164.59 \pm \\
16.02^{\mathrm{ab}}\end{array}$ & $\begin{array}{c}248.98 \pm \\
21.50^{\mathrm{ab}}\end{array}$ & $\begin{array}{c}251.99 \pm \\
17.80^{\mathrm{B}}\end{array}$ & $\begin{array}{c}250.29 \pm \\
13.30\end{array}$ & & & & & & & \\
\hline & Mean & $\begin{array}{c}243.73 \pm \\
26.2\end{array}$ & $\begin{array}{c}164.22 \pm \\
16.43\end{array}$ & $\begin{array}{c}164.30 \pm \\
22.26\end{array}$ & $\begin{array}{c}190.75 \pm \\
13.28^{\mathrm{M}}\end{array}$ & $\begin{array}{c}594.80 \pm \\
164.26\end{array}$ & $\begin{array}{c}135.36 \pm \\
11.32\end{array}$ & $\begin{array}{c}233.45 \pm \\
11.00\end{array}$ & $\begin{array}{c}321.20 \pm \\
50.08^{\mathrm{N}}\end{array}$ & & & & & & & & \\
\hline \multirow{3}{*}{ GPX } & Fed & $\begin{array}{c}85.21 \pm \\
1.86^{\mathrm{abc}}\end{array}$ & $\begin{array}{c}91.58 \pm \\
2.47^{\mathrm{bc}}\end{array}$ & $\begin{array}{c}84.49 \pm \\
0.00^{\mathrm{abc}}\end{array}$ & $\begin{array}{c}87.09 \pm \\
1.14^{\mathrm{AB}}\end{array}$ & $\begin{array}{c}102.86 \pm \\
1.93^{c}\end{array}$ & $\begin{array}{c}118.34 \pm \\
21.47^{\mathrm{bc}}\end{array}$ & $\begin{array}{c}87.24 \pm \\
1.01^{\mathrm{bc}}\end{array}$ & $\begin{array}{c}102.82 \pm \\
7.31^{\mathrm{B}}\end{array}$ & $\begin{array}{c}94.96 \pm \\
3.79^{Y}\end{array}$ & \multirow{3}{*}{$S$} & \multirow{3}{*}{$\mathrm{S}$} & \multirow{3}{*}{ NS } & \multirow{3}{*}{ NS } & \multirow{3}{*}{$S$} & \multirow{3}{*}{ NS } & \\
\hline & Starved & $\begin{array}{c}70.02 \pm \\
5.52^{\mathrm{ab}}\end{array}$ & $\begin{array}{c}93.17 \pm \\
3.17^{\mathrm{bc}}\end{array}$ & $\begin{array}{c}75.67 \pm \\
3.01^{\mathrm{ab}}\end{array}$ & $\begin{array}{c}79.62 \pm \\
2.82^{A}\end{array}$ & $\begin{array}{c}81.45 \pm \\
0.80^{\mathrm{abc}}\end{array}$ & $\begin{array}{c}91.00 \pm \\
2.49^{\mathrm{bc}}\end{array}$ & $\begin{array}{c}64.38 \pm \\
3.19^{\mathrm{a}}\end{array}$ & $\begin{array}{c}78.94 \pm \\
2.29^{A}\end{array}$ & $\begin{array}{c}79.28 \pm \\
1.80^{x}\end{array}$ & & & & & & & NS \\
\hline & Mean & $\begin{array}{c}77.62 \pm \\
3.26\end{array}$ & $\begin{array}{c}92.38 \pm \\
1.97\end{array}$ & $\begin{array}{c}80.08 \pm \\
1.73\end{array}$ & $\begin{array}{c}83.36 \pm \\
1.57^{\mathrm{M}}\end{array}$ & $\begin{array}{c}92.16 \pm \\
2.46\end{array}$ & $\begin{array}{c}104.67 \pm \\
10.95\end{array}$ & $\begin{array}{c}75.81 \pm \\
2.89\end{array}$ & $\begin{array}{c}90.88 \pm \\
4.06^{\mathrm{M}}\end{array}$ & & & & & & & & \\
\hline & Fed & $\begin{array}{c}186.17 \pm \\
11.53^{b}\end{array}$ & $\begin{array}{c}148.35 \pm \\
4.07^{\mathrm{ab}}\end{array}$ & $\begin{array}{c}85.74 \pm \\
0.00^{\mathrm{a}}\end{array}$ & $\begin{array}{c}140.09 \pm \\
8.04^{\mathrm{B}}\end{array}$ & $\begin{array}{c}443.57 \pm \\
61.2^{\mathrm{c}}\end{array}$ & $\begin{array}{c}157.48 \pm \\
5.38^{\mathrm{ab}}\end{array}$ & $\begin{array}{c}180.52 \pm \\
7.99^{\mathrm{ab}}\end{array}$ & $\begin{array}{c}260.52 \pm \\
29.71^{\mathrm{C}}\end{array}$ & $\begin{array}{c}200.30 \pm \\
16.87^{Y}\end{array}$ & & & & & & & \\
\hline TAC & Starve & $\begin{array}{c}117.91 \pm \\
10.09^{\mathrm{a}}\end{array}$ & $\begin{array}{c}85.09 \pm \\
3.70^{\mathrm{a}}\end{array}$ & $\begin{array}{c}94.93 \pm \\
7.67^{\mathrm{a}}\end{array}$ & $\begin{array}{c}99.31 \pm \\
4.86^{\mathrm{A}}\end{array}$ & $\begin{array}{c}182.48 \pm \\
9.87^{\mathrm{ab}}\end{array}$ & $\begin{array}{c}166.39 \pm \\
5.84^{\mathrm{ab}}\end{array}$ & $\begin{array}{c}145.52 \pm \\
6.93^{\mathrm{ab}}\end{array}$ & $\begin{array}{c}164.80 \pm \\
5.03^{\mathrm{B}}\end{array}$ & $\begin{array}{c}132.05 \pm \\
5.21^{x}\end{array}$ & $\mathrm{~S}$ & $S$ & S & $\mathrm{S}$ & $S$ & $\mathrm{~S}$ & $S$ \\
\hline & Mean & $\begin{array}{c}152.04 \pm \\
10.33\end{array}$ & $\begin{array}{c}116.72 \pm \\
7.12\end{array}$ & $\begin{array}{c}90.33 \pm \\
3.87\end{array}$ & $\begin{array}{c}119.70 \pm \\
5.26^{\mathrm{M}}\end{array}$ & $\begin{array}{c}313.02 \pm \\
40.7\end{array}$ & $\begin{array}{c}161.93 \pm \\
3.99\end{array}$ & $\begin{array}{c}163.02 \pm \\
6.33\end{array}$ & $\begin{array}{c}212.66 \pm \\
16.00^{\mathrm{N}}\end{array}$ & & & & & & & & \\
\hline & Fed & $\begin{array}{c}20.56 \pm \\
3.48^{\mathrm{b}}\end{array}$ & $\begin{array}{c}28.07 \pm \\
2.93^{\mathrm{b}}\end{array}$ & $\begin{array}{c}16.31 \pm \\
0.00^{\mathrm{a}}\end{array}$ & $\begin{array}{c}21.65 \pm \\
1.69^{\mathrm{A}}\end{array}$ & $\begin{array}{c}22.51 \pm \\
1.26^{\mathrm{b}}\end{array}$ & $\begin{array}{c}31.02 \pm \\
2.73^{\text {bc }}\end{array}$ & $\begin{array}{c}22.62 \pm \\
0.13^{b}\end{array}$ & $\begin{array}{c}25.38 \pm \\
1.18^{\mathrm{B}}\end{array}$ & $\begin{array}{c}23.51 \pm \\
1.05\end{array}$ & & & & & & & \\
\hline SMC & Starved & $\begin{array}{c}31.15 \pm \\
1.5^{c}\end{array}$ & $\begin{array}{c}24.30 \pm \\
2.13^{\mathrm{b}}\end{array}$ & $\begin{array}{c}13.42 \pm \\
2.49^{a}\end{array}$ & $\begin{array}{c}22.951 \pm \\
70^{\mathrm{AB}}\end{array}$ & $\begin{array}{c}23.57 \pm \\
3.82^{b}\end{array}$ & $\begin{array}{c}21.69 \pm \\
0.53^{\mathrm{b}}\end{array}$ & $\begin{array}{c}20.67 \pm \\
1.71^{\mathrm{b}}\end{array}$ & $\begin{array}{c}21.98 \pm \\
1.38^{\mathrm{B}}\end{array}$ & $\begin{array}{c}22.47 \pm \\
1.09\end{array}$ & NS & $\mathrm{S}$ & NS & $\mathrm{S}$ & NS & $\mathrm{S}$ & NS \\
\hline & Mean & $\begin{array}{c}25.85 \pm \\
2.16\end{array}$ & $\begin{array}{c}26.18 \pm \\
1.81\end{array}$ & $\begin{array}{c}14.87 \pm \\
1.26\end{array}$ & $\begin{array}{c}22.30 \pm \\
1.19^{\mathrm{M}}\end{array}$ & $\begin{array}{c}23.04 \pm \\
1.97\end{array}$ & $\begin{array}{c}26.36 \pm \\
1.67\end{array}$ & $\begin{array}{c}21.64 \pm \\
0.86\end{array}$ & $\begin{array}{c}23.68 \pm \\
0.93^{\mathrm{M}}\end{array}$ & & & & & & & & \\
\hline & Fed & $\begin{array}{c}165.62 \pm \\
8.48^{\mathrm{ab}}\end{array}$ & $\begin{array}{c}120.28 \pm \\
4.36^{\mathrm{ab}}\end{array}$ & $\begin{array}{c}69.43 \pm \\
0.00^{\mathrm{a}}\end{array}$ & $\begin{array}{c}118.44 \pm \\
7.32^{\mathrm{B}}\end{array}$ & $\begin{array}{c}421.05 \pm \\
61.2^{\mathrm{c}}\end{array}$ & $\begin{array}{c}126.46 \pm \\
6.90^{\mathrm{ab}}\end{array}$ & $\begin{array}{c}157.91 \pm \\
7.93^{\mathrm{ab}}\end{array}$ & $\begin{array}{c}235.14 \pm \\
30.03^{\mathrm{c}}\end{array}$ & $\begin{array}{c}176.79 \pm \\
16.84^{Y}\end{array}$ & & & & & & & \\
\hline PAC & Starved & $\begin{array}{c}86.77 \pm \\
10.25^{\mathrm{a}}\end{array}$ & $\begin{array}{c}60.79 \pm \\
2.39^{a}\end{array}$ & $\begin{array}{c}81.51 \pm \\
7.37^{\mathrm{a}}\end{array}$ & $\begin{array}{c}76.36 \pm \\
4.57^{A}\end{array}$ & $\begin{array}{c}158.91 \pm \\
12.7^{\mathrm{ab}}\end{array}$ & $\begin{array}{c}144.70 \pm \\
6.21^{\mathrm{ab}}\end{array}$ & $\begin{array}{c}124.85 \pm \\
7.82^{\mathrm{ab}}\end{array}$ & $\begin{array}{c}142.82 \pm \\
5.75^{\mathrm{B}}\end{array}$ & $\begin{array}{c}109.59 \pm \\
5.37^{x}\end{array}$ & $\mathrm{~S}$ & $\mathrm{~S}$ & $S$ & $S$ & $S$ & $S$ & $S$ \\
\hline & Mean & $\begin{array}{c}126.19 \pm \\
10.48\end{array}$ & $\begin{array}{c}90.53 \pm \\
6.66\end{array}$ & $\begin{array}{c}75.47 \pm \\
3.82\end{array}$ & $\begin{array}{c}97.40 \pm \\
4.96^{\mathrm{M}}\end{array}$ & $\begin{array}{c}289.98 \pm \\
41.0\end{array}$ & $\begin{array}{c}135.58 \pm \\
4.92\end{array}$ & $\begin{array}{c}141.38 \pm \\
6.45\end{array}$ & $\begin{array}{c}188.98 \pm \\
16.14^{\mathrm{N}}\end{array}$ & & & & & & & & \\
\hline
\end{tabular}

Data expressed as mean \pm SE $(n=4)$. All significance are measured at $P<0.05$. Different small superscript $(a, b, c, d$, etc.) represent the level of significance among different treatment groups at different sampling points for a particular parameter. Different capital superscript (A, B, C) represents significant difference between means of different experimental groups (fed-placebo, starved-placebo, fed-infected and starved-infected groups). Overall mean value having different capital superscript (M \& $\mathrm{N}, \mathrm{X} \& \mathrm{Y}$ ) vary significantly. S-Significant, NS-Non-significant. Units: Superoxide dismutase (SOD) - units $\mathrm{mg} \mathrm{protein}^{-1}$; Catalase (CAT) - units mg protein ${ }^{-1}$; Glutathione peroxidase (GPX) - nmol $\mathrm{min}^{-1} \mathrm{ml}^{-1}$; Total anti-oxidation capacity (TAC) - $\mathrm{mM}$ trolox equivalent; Small molecule anti-oxidation capacity (SMC) - mM trolox equivalent; Protein anti-oxidation capacity (PAC) $-\mathrm{mM}^{\text {trolox equivalent }}{ }^{-1}$

Table 3: Effect of starvation (St), E. tarda infection (I), treatment time (T) and their interactions on serum stress enzymes activity in $P$. major.

reduced significantly $(\mathrm{P}<0.05)$ in the starved-infected group (Table 3$)$. Starvation and infection interactively had a significant effect $(\mathrm{P}<0.05)$ on the GPX activity.

Similar to other antioxidant markers, SMC and PAC values were significantly $(\mathrm{P}<0.05)$ altered after infection (Table 3$)$. The TAC values showed significant increase in the fed-infected groups as compared to the starved-infected groups (Table 3 ).

\section{Transcriptional changes}

In spleen, except for 10 dai, $T N F \alpha$ levels did not differ among the various experimental groups (Figure 6A). At 10 dai, starved group samples had higher TNF $\alpha$ expression than its fed counterparts. Although similar results were observed for $I L^{-1} \beta$, the differences were more pertinent (Figure 6B). MHCIIA expressions were gradually upregulated in the starved groups at all-time points (Figure $6 \mathrm{C}$ ). In case of chemokines, starvation induced spleenic IL8 expression in a time dependent manner, which upon infection increased more steeply (Figure 6D). However, the fed-infected group showed sudden increase in IL8 expression and later became static at 5 and 10 dai.

\section{Programmed cell death analysis in gill lamellae}

In order to analyses the starvation associated programmed cell death in the gill lamellae, we performed two-colored immunohistochemistry of the gills, using Annexin V (apoptosis cell death marker) and Beclin1 (autophagic cell death marker) antibodies. The fed-placebo (Figure 7A) group showed comparatively lesser Annexin V stained cells than the starved-placebo (Figure 7B) group. The fed- infected (Figure 7C) group showed numerous Annexin stained cells. The starved-placebo group had a moderate amount of Annexin V/Beclin1 double stained cells, which however, increased multi-fold in the starved-infected (Figure 7D) group.

\section{Evaluation of disease resistance capability}

When compared to fed-placebo group, survivability of both starved groups didn't show any significant difference at 0 and 5 dai, however, slightly reduced at 10 dai (Figure 8 ). On the other hand, survivability of fed-infected group decreased gradually at different time points. Evidently, the starved- infected group showed better survivability than the fed-infected group. 
Citation: Mohapatra S, Chakraborty T, Kacem RH, Shimizu S, Matsubara T, et al. (2016) Starvation: An Alternate Measure to Improve Immunity and Physiology of Red Sea Bream During Edwardsiella Tarda Infection. J Aquac Res Development S2: 007. doi:10.4172/2155-9546.S2-007

A

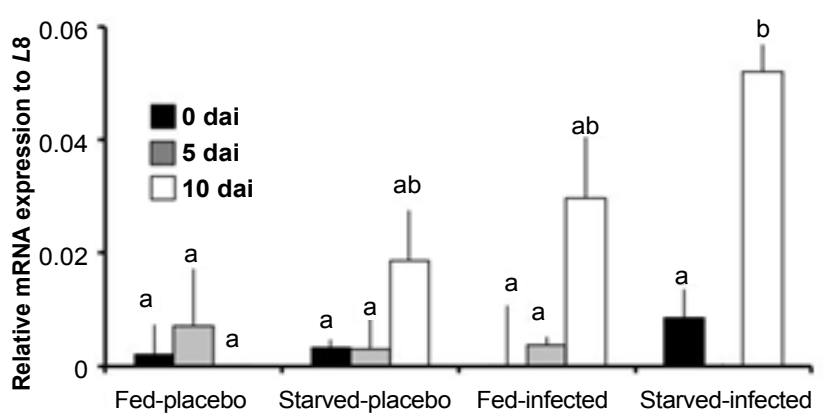

Groups

B

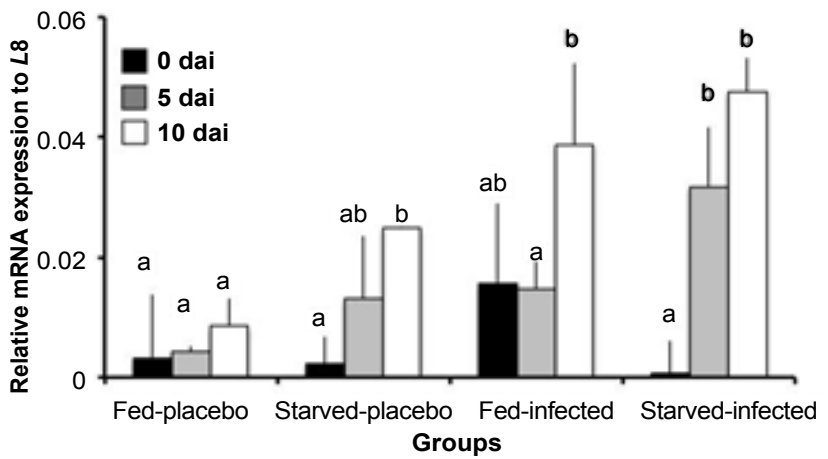

\section{C}

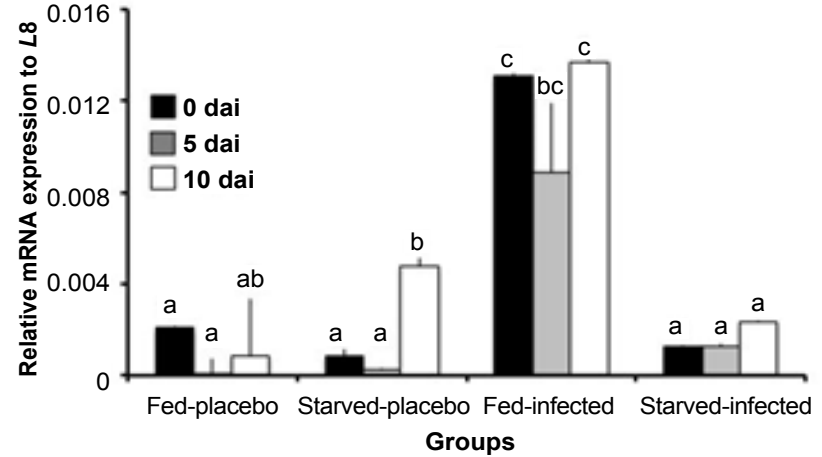

D

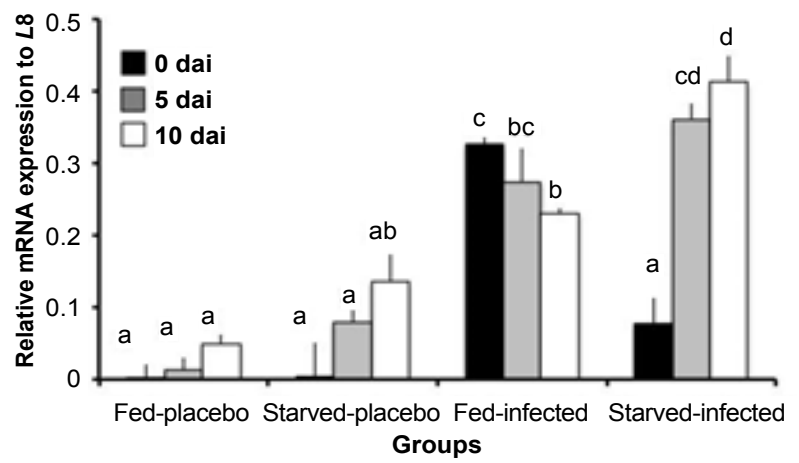

Figure 6: mRNA expression analysis of cytokines by Real-time PCR. Changes in mRNA level of TNFa (A), IL-1 $13(B)$, MHCIIA (C) and IL8 (D) are plotted on Y-axis against different experimental groups. Data are shown as the mean \pm SE, and expressed as relative abundance corrected for $L 8$. Letters above the bars indicate that these groups differ significantly from each other at $\mathrm{P}<0.05$.
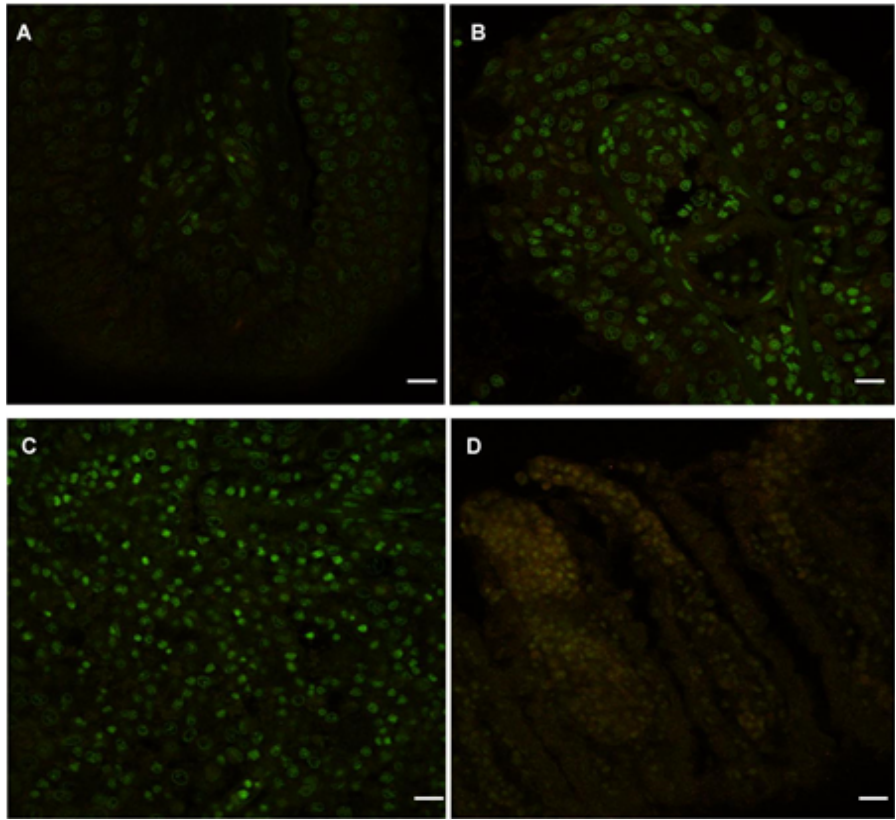

D

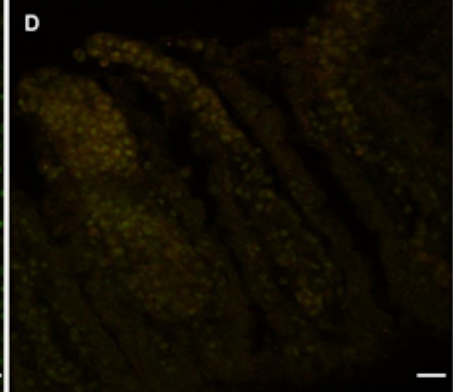

Figure 7: Starvation and infection associated programmed cell death in the gill lamellae. Two-colored immunohistochemical analysis, using Annexin $\mathrm{V}$ (green) and Beclin1 (red), was done to evaluate the programmed cell death in the gill lamellaes of Fed-placebo (A), Starved-placebo (B), Fed-infected group (C), and Starvedinfected (D) groups at 10 dai. Bar length $-20 \mu \mathrm{m}$. 


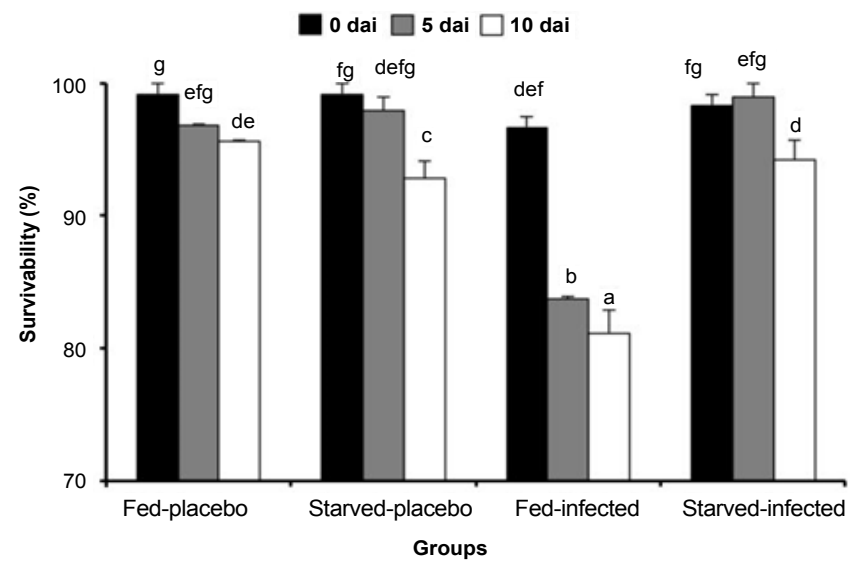

Figure 8: Evaluation of survivability of different experimental groups. Data are shown as the mean $\pm \mathrm{SE}$, and letters above the bars indicate that these groups differ significantly from each other at $\mathrm{P}<0.05$

A descriptive statistical analysis was made to obtain a global idea about the DRI and its variability between groups. The mean, the standard deviation, the minimum and the maximum values of the DRI for each grouping criteria are represented in Table 4 . Based on the comparison of the means, we found that the fed-infected fish, followed by starved-infected and starved-placebo fish had the lowest average disease resistance. As expected, the fed-placebo group showed the best average resistance. More detailed explanation about the statistical evaluation of DRI and the effects of infection (Supplementary Table 2) and starvation (Supplementary Table 3) on overall fish condition are given in the supplementary information (Supplementary Information 1).

\section{Discussion}

Starvation, during an immune-compromised situation, has been known to be an effective management strategy in curbing the infection-related mortality in numerous organisms [11,14]. In the present study, short-term starvation resulted in a drastic reduction in the E. tarda content in both spleen and muscle, along with the increase in several iron homeostasis related genes. We also recorded positive alterations in the blood and serum parameters, cytokine production, mucus cell number and gill morphology in the starved fish. Moreover, we observed that, upon E. tarda infection, the starved fish exhibited enhanced survivability in comparison to the fed counterparts. Thus, the present study highlights the importance of short-term starvation in helping the animal to mount an immunological response during $E$. tarda infection, and successfully fighting against the disease.

Bacteria generally use the host's circulating free metal ions to propagate inside the host $[22,23]$. Nutrient, especially iron, withholding is an important host defense mechanism during bacterial infection, which suppresses bacterial outgrowth [22]. The major regulators of iron homeostasis i.e. Hepcidin, Transferrin, Ferritin, etc., are influenced by both starvation and infection. Recently, Lin et al. [23] showed that addition of Transferrin could improve the health of infected mice probably by disrupting the microbial transmembrane potential and sequestering the free nutrient iron content in the body [22,24]. Similarly, we also observed a significant $(\mathrm{P}<0.05)$ increase in Transferrin expression in the spleenic cells of starved-infected fish. It is noteworthy to mention that, Transferrin only binds and transports the free iron but Hepcidin helps to store the iron inside different cells and tissue, which reduces the circulating concentration of iron in the serum [25]. Similar to transferrin, we also observed increased Hepcidin 1 and 2 mRNA expressions in starved-infected fish than the fed-infected groups, which may indicate a conserved iron sequestering mechanism, prevalent in fish, that in-turn helps to fight against bacterial infections. These high levels of iron regulatory genes in the starved groups highlights the tugof-war over iron between the host and the invading bacteria [26], and further aids in impeding the growth of the pathogenic bacteria due to reduced iron concentration in the host body.

Iron is also an essential component for erythropoiesis [27], oxygen transport (via hemoglobin) [26], bacterial sustainability [22] and other cellular mechanisms. Starvation is instrumental in reducing the circulating iron in the body by increasing the tissue iron retention rate [28]. Free circulating iron content and hemoglobin concentration are correlated in various organisms [29]. According to Lim and Klesius [30], four weeks starved channel catfish exhibited significant reduction in the hemoglobin content. However, we found no significant difference in the hemoglobin content between the fed and starved-placebo groups. Similar to our data in red sea bream, many other research groups also reported that prolonged starvation did not alter the hemoglobin content in other fish species, eg. Olive flounder (Paralichthys olivaceus) [31], Red progy (Pagrus pagrus) [32]. Unlike starvation, infection is a ubiquitously known factor for reducing hemoglobin content in various fish species [33]. In our present work, upon infection, the hemoglobin content was significantly $(\mathrm{P}<0.05)$ reduced in both the starved and fed group, which might suggest an alternative mode of hemoglobin reduction, via reduced availability of certain amino acid and protein in fish [34]. Mohapatra et al. [17] also reportedsignificantly low hemoglobin content in the Aeromonas hydrophila infected Labeo rohita fingerlings than the non-infected fish.

Starvation is known to alter the blood glucose concentration, depending on the duration of starvation, interspecies variability, age, and others [35-37]. Several fish species either utilize their stored liver glycogen for the maintenance of metabolic functions during short term starvation $[38,39]$ or reduce the rate of glucose utilization by increasing the gluconeogenesis process $[39,40]$. In our present study, we recorded no remarkable changes in the plasma glucose concentrations among all the different experimental groups at 0 and 5 dai, but a slight reduction was noticed in the 10 dai starved groups. This reduction in the blood

\begin{tabular}{|c|c|c|c|c|c|}
\hline $\begin{array}{c}\text { Grouping } \\
\text { criteria }\end{array}$ & $\begin{array}{c}\text { Treatment } \\
\text { groups }\end{array}$ & Mean & $\begin{array}{c}\text { Standard } \\
\text { deviation }\end{array}$ & Min & Max \\
\hline 0dai & Placebo & 60.09 & 3.56 & 56.28 & 67 \\
\hline & Infected & 47.99 & 5.86 & 37.23 & 55.48 \\
\hline & Total & 54.04 & 7.81 & 37.23 & 67 \\
\hline 5 dai & Placebo & 52.71 & 2.81 & 48.97 & 56.53 \\
\hline & Infected & 52.32 & 2.24 & 49.91 & 56.09 \\
\hline & Total & 52.51 & 2.46 & 48.97 & 56.53 \\
\hline 10dai & Placebo & 49.1 & 3.78 & 45.02 & 55.02 \\
\hline & Infected & 46.71 & 2.16 & 42.62 & 49.09 \\
\hline & Total & 47.91 & 3.22 & 42.62 & 55.02 \\
\hline Starved & Placebo & 51.85 & 5.7 & 45.02 & 60.14 \\
\hline & Infected & 50.1 & 3.06 & 47.14 & 55.48 \\
\hline & Total & 50.98 & 4.56 & 45.02 & 60.14 \\
\hline Fed & Placebo & 56.08 & 5.06 & 49 & 67 \\
\hline & Infected & 47.91 & 5.34 & 37.23 & 56.09 \\
\hline & Total & 51.99 & 6.58 & 37.23 & 67 \\
\hline
\end{tabular}

Table 4: Descriptive statistical analysis of the effect of treatment time and food on overall disease resistance index (DRI). 
glucose level might indicate that the rate of glucose production bygluconeogenesis was not sufficient to negate the effect of starvation for a longer period of time [39].

Serum profiling is essential in assessing the physiological status of any animal. Any change in the serum condition is reflective of the physiological, nutritional and pathological condition of the animal. The reduced serum protein level and the simultaneous increase in the $A: G$ in the fed-infected group points towards the stressful condition of the fish due to bacterial infection $[41,42]$. Oxidative stress eventuates when the rate of production of ROS (reactive oxygen species) surpasses the scavenging capacity of the antioxidants [43], resulting in the damage of several cellular components [44]. Several anti-oxidant enzymes such as SOD, which curb the potentially toxic superoxide radical, CAT and GPX, which hydrolyse and controls the $\mathrm{H}_{2} \mathrm{O}_{2}$ in the body, are responsible in ameliorating the stress response of the animal [45]. Bacterial infection is known to compromise the immune system of the fish [17], mostly by increasing the ROS production leading to severe oxidative stress. In this study, we observed higher levels of all the three stress enzymes (SOD, CAT, GPX) in the fed-infected groups, which is indicative of higher oxidative stress level that could have resulted due to the $E$. tarda infection [46]. The decreased levels in the SOD and CAT levels in the starved-infected groups could correlated with increased resistance to oxidative stress due to the effect of prior starvation [47]. Although we had expected a more pronounced SOD and CAT level in the gills, since it the primary contact site for water borne pathogenic exposure, very low levels of these enzymes were observed in comparison to the serum. This could indicate that the pro-oxidation capacity is quite low in the gills than the other organs [43].

Antioxidants play a vital role in preventing the formation of and scavenging of free radicals and other potentially toxic oxidizing species. The total antioxidant capacity (TAC) of fish acts as a reliable biomarker for stress as it exhibits the metabolic capacity of both the antioxidant enzymatic and non- enzymatic system to external stimuli $[48,49]$. We observed a significant increase in the TAC value in the fedinfected group, which however decreased substantially in the starvedinfected group. In the present investigation, E. tarda infection might be responsible for the increase in the oxidative stress which could have led to the up-regulation antioxidants in the fish [50].

As we have discussed earlier, starvation might be an integral part of immune enhancement of fish, probably by the improvement of innate immunity. The essentiality of cell-mediated immunity in the host defense against bacterial infection is well documented in mammals $[51,52]$. In fish, upon pathogenic infection, pro-inflammatory cytokines (IL-1 $\beta$ and TNF $\alpha$ ), secreted by the activated immune- related cells (macrophages, neutrophil, lymphocytes etc), results in eliciting major immune responses [53,54]. TNFa is also responsible for various other host responses, including cell proliferation, differentiation, apoptosis, necrosis, and induction of other cytokines [55]. In the present study, up- regulated expression of the pro-inflammatory cytokines was recorded both after starvation and infection; suggesting the action of various inflammatory stimuli, working alone or in combination, to induce such response. Several studies with zebra fish (Danio rerio), carp, etc., have showed that experimental infection with $E$. tarda resulted in differential acute alteration of the inflammatory cytokines, $I L-1 \beta$ and $T N F \alpha[56,57]$. Similar increased immune responses, especially $I L-1 \beta$ expression, were reported in Atlantic char when the starved fish were treated with lipopolysaccharides (LPS) [58]. This increased immune response might have caused an energy demanding condition, thereby resulting in a unique metabolic alteration in order to deal with the extreme stress without eliciting immune suppression [58]. Since a brief bacterial challenge resulted in gradual up-regulation of these cytokines, it can be considered that they follow a similar activation mechanism probably via endothelial cell mediated or cortisol induced cytokine production $[59,60]$. Cytokines and chemokines are the major innate immune response mediators and their expression is the key marker of immune function [61]. IL8, an important chemokine, is excessively produced in response to several stimuli (LPS or Poly I:C). In present study, similar elevated IL8 and MHCIIA levels were observed in the infected groups, suggesting that chemokines play a significant role in the immune boosting or host innate defense after $E$. tarda infection.

Similar to mammals and other teleosts, our results also demonstrated the importance of both cell-mediated and innate immunity in safeguarding against intracellular bacterial infection [52]. In the present investigation, all the studied immune-related genes, although showed an increasing trend along with days of starvation, no significant difference was observed between the fed and starved fish, which could suggest that these animals were capable of withstanding starvation related stress conditions (especially the energy demand) without hampering the immune status [58]. However, after infection, majority of the genes were significantly $(\mathrm{P}<0.05)$ increased in the starved fish than their fed counterparts. A plausible explanation for this increase could be that the host defense mechanism was initiated and the levels of cytokines were raised to a higher level in starved fish, which gave them an upper-hand in terms of immune enhancement. Similar observations were recorded regarding the DRI, where the starved-infected group had better response than the fed-infected ones, suggesting that some unknown mechanism are at work in the starved fish which facilitates in the immune status fish.

Gill is one of the major doorways for pathogenic entry in fish owing to its direct exposure to the external environment $[17,62]$. Mucus secretion from epithelial cells of the gill is considered to the first hand response against any kind of stress or infection. Mucus contains many active components including proteases, antimicrobial peptides, lysozymes, which are long known to protect the organism from external bacterial or parasitic invasion $[63,64]$. Our gill histological observations depicted maximum gill lamella degradation and blood vessels deterioration in the fed-infected fish at 10 dai, which could be indicative of the harmful effect of $E$. tarda infection. However, the starved-infected fish portrayed slightly lesser gill damage than its fed partners, accentuating the beneficial role of starvation during infection. This improved condition of the animal might be associated with several factors (i) mucus production was increased beforehand, due to starvation which creates a physical barrier for direct bacterial invasion in the starved- infected fish [63] (ii) improved oxidative stress response and antioxidants profile might have alleviated the cells from bacterial induced stress (iii) Starvation could have resulted in activation of certain autophagic reaction which in turn protected the fish against the harmful pathogenic bacteria $[47,65]$.

\section{Conclusion}

In relation to this, we also observed better survivability in the starved-infected groups than fed- infected ones. Interestingly, DRI also showed a similar trend with the survivability of fish, which although decreased in starved groups (compared to fed-placebo) but remained significantly higher than fed-infected ones. This suggests that starvation, even though undesirable for a lengthy period of time, can be a boon for preventing infection in fish. Additionally, DRI could be a new global index for assessing the overall fish health. 
Citation: Mohapatra S, Chakraborty T, Kacem RH, Shimizu S, Matsubara T, et al. (2016) Starvation: An Alternate Measure to Improve Immunity and Physiology of Red Sea Bream During Edwardsiella Tarda Infection. J Aquac Res Development S2: 007. doi:10.4172/2155-9546.S2-007

Page 11 of 12

The data presented in this study clearly shows that starvation is beneficial in controlling bacterial invasion in red sea bream. Although our data suggests that multiple pathways i.e. free iron regulation, antioxidant production, oxidative stress response, phagocytosis, cytokine and chemokine production, autophagic induction are important for total resistance, the inter-relating factors/mechanisms needs further investigation to get a comprehensive idea about starvation induced disease resistance mechanism in fish.

\section{Conflict of Interest Statement}

None of the authors of this paper has a financial or personal relationship with other people or organizations that could inappropriately influence or bias the content of the paper.

\section{Acknowledgment}

This work was supported by Japan Society for the Promotion of Science (JSPS) Kakenhi Grant Number 23688022; Strategic Information and Communications R\&D Promotion Programme, Ministry of Internal Affairs and Communications (MIC) Grant Number 15654007; Ministry of Agriculture, Forestry and Fisheries Grant Number 15650503; and Regional Innovation Strategy Support Program 2012 Ministry of Education, Culture, Sports, Science and Technology (MEXT).

\section{Author Contributions}

Conceived and designed the experiments: SM TC. Performed the experiments: SM TC. Analyzed the data: SM TC RHK. Contributed reagents/materials/analysis tools: SS TM KO. Wrote the paper: SM TC.

\section{References}

1. Ling SHM, Wang $X H$, Xie L, Lim TM, Leung KY (2000) Use of green fluorescent protein (GFP) to study the invasion pathways of Edwardsiella tarda in in vivo and in vitro fish models. Microbiology 146: 7-19.

2. Castro N, Toranzo AE, Barja JL, Nunez S, Magarinos B (2006) Characterization of Edwardsiella tarda strains isolated from turbot, Psetta maxima (L.). Journal of Fish Disease 29: 541-547.

3. Mohanty BR, Sahoo PK (2007) Edwardsiellosis in fish: a brief review. J. Biosc 32: $1331-1344$

4. Park SB, Aoki T, Jung TS (2012) Pathogenesis of and strategies for preventing Edwardsiella tarda infection in fish. Veterinary Research 43: 67.

5. Matsuyama T, Kamaishi T, Ooseko N, Kurohara K, lida T (2005) Pathogenicity of motile and non-motile Edwardsiella tarda to some marine fish. Fish Pathology 40: $133-136$

6. Kyriazakis I, Tolkamp BJ, Hutchings MR (1998) Towards a functional explanation for the occurrence of anorexia during parasitic infections. Animal Behaviour 56: 265-274

7. Husband AJ (1995) The immune system and integrated homeostasis Immunology and Cell Biology 73: 377-378.

8. Anson RM, Guo Z, deCabo R, Iyun T, Rios M, et al. (2003) Intermittent fasting dissociates beneficial effects of dietary restriction on glucose metabolism and neuronal resistance to injury from calorie intake. Proceedings of the National Academy of Sciences USA 100: 6216-6220.

9. Ayres JS, Schneider DS (2009) The role of anorexia in resistance and tolerance to infections in Drosophila. PLoS Biology 7: e1000150.

10. Dantzer R (2004) Cytokine-induced sickness behaviour: a neuroimmune response to activation of innate immunity. European Journal of Pharmacology 500: 399-411.

11. Adamo SA, Bartlett A, Le J, Spencer N, Sullivan K (2010) Illness-induced anorexia may reduce trade-offs between digestion and immune function. Animal Behaviour 79: 3-10.

12. Martin SAM, Douglas A, Houlihan DF, Secombes CJ (2010) Starvation alters the livertranscriptome of the innate immune response in Atlantic salmon (Salmo salar). BMC Genomics 11: 418

13. Damsgard B, Mortensen A, Sommer Al (1998) Effects of infectious pancreatic necrosis virus (IPNV) on appetite and growth in Atlantic salmon, Salmo salar $\mathrm{L}$. Aquaculture 163: 185-193.
14. Wise DJ, Johnson MR (1998) Effect of feeding frequency and Rometmedicated feed on survival, antibody response, and weight gain of fingerling channel catfish Ictalurus punctatus after natural exposure Edwardsiella ictaluri. Journal of World Aquaculture Society 29: 169-175.

15. Rodriguez R, Jung CL, Gabayan V, Deng JC, Ganz T, et al. (2014) Hepcidin induction by pathogens and pathogen-derived molecules is strongly dependent on interleukin-6. Infection and Immunity 82: 745-752.

16. Ye J, Keller JN (2010) Regulation of energy metabolism by inflammation: A feedback response in obesity and calorie restriction. Aging 2: 361-368.

17. Mohapatra S, Chakraborty T, Prusty AK, Pani Prasad K, Mohanta KN (2014a) Dietary multispecies probiotic supplementation enhances the immunohematological responses and reduces mortality by Aeromonas hydrophila in Labeo rohita fingerlings. Journal of World Aquaculture Society 45: 532-544.

18. Mohapatra S, Chakraborty T, Prusty AK, Das P, Pani PK, et al. (2012) Use of different microbial probiotics in the diet of rohu, Labeo rohita fingerlings: effects on growth, nutrient digestibility and retention, digestive enzyme activities and intestinal microflora. Aquaculture Nutrition 18: 1-11.

19. Mohapatra S, Chakraborty T, Prusty AK, Pani PK, Mohanta KN (2014b) Beneficial effects of dietary probiotics on hemato-immunology and cell apoptosis of Labeo rohita fingerlings reared at higher water temperatures. PLoS One 9: e100929.

20. Kiernan JA (2008) Histological and histochemical methods theory and practice. (4thedn), Oxfordshire, Scion Publishing Limited, UK.

21. Yu XG, Wu LM, Xie L, Yang SJ, Chakraborty T, et al. (2014) Characterization of two paralogous StAR genes in a teleost, Nile tilapia (Oreochromis niloticus). Molecular and Cellular Endocrinology 392): 152-162.

22. Skaar EP (2010) The battle for iron between bacterial pathogens and their vertebrate hosts. PLoS Pathogens 6: e1000949.

23. Lin L, Pantapalangkoor P, Tan B, Bruhn KW, Ho T, et al. (2014) Transferrin iron starvation therapy for lethal bacterial and fungal infections. Journal of Infectious Diseases 210: 254-264.

24. Brandsma ME, Jevnikar AM, Ma S (2011) Recombinant human transferring: beyond iron binding and transport. Biotechnology Advances 29: 230-238.

25. 25. Cadadei E, Bird S, Gonzalez-Vecino JL, Wadsworth S, Secombes CJ (2013) The effect of peptidoglycan enriched diets on antimicrobial peptide gene expression in rainbow trout (Oncorhynchus mykiss). Fish and Shellfish Immunology 34: 529-537.

26. Ganz T (2003) Hepcidin - a key regulator of iron metabolism and mediator of anemia of inflammation. Blood 102: 783-788.

27. Mast AE, Lee TH, Schlumpf KS, Wright DJ, Johnson B, et al. (2012) The impact of HFE mutations on haemoglobin and iron status in individuals experiencing repeated iron loss through blood donation. British Journal of Haematology 156 388-401.

28. Vecchi C, Montosi G, Garuti C, Corradini E, Sabelli M, et al. (2014) Gluconeogenic signals regulate iron homeostasis via hepcidin in mice. Gastroenterology 146: 1060-1069.

29. Mercadel L, Metzger M, Haymann JP, Thervet E, Boffa JJ, et al. (2014) The relation of hepcidin to iron disorders, inflammation and hemoglobin in chronic kidney disease. PLoS One 9: e99781.

30. Lim C, Klesius PH (2003) Influence of feed deprivation on hematology macrophage chemotaxis, and resistance to Edwardsiella ictaluri challenge of channel catfish. Journal of Aquatic Animal Health 15: 13-20.

31. Kim JH, Jeong MH, Jun JC, Kim TI (2014) Changes in hematological biochemical and non-specific immune parameters of Olive Flounder, Paralichthys olivaceus, following starvation. Asian-Australasian Journal of Animal Sciences 27: 1360-1367.

32. Caruso G, Denaro MG, Caruso R, Genovese L, Mancari F et al. (2012) Short fasting and re-feeding in red porgy (Pagrus pagrus, Linnaeus 1758): Response of some haematological, biochemical and non-specific immune parameters. Marine Environmental Research 81: 18-25.

33. Sebastiao FA, Nomura D, Sakabe R, Pilarski F (2011) Hematology and productive performance of Nile Tilapia (Oreochromis niloticus) naturally infected with Flavobacterium columnare. Brazilian Journal of Microbiology 42: 282-289.

34. Sakamoto S, Yone Y (1978) Requirement of red sea bream for dietary iron Bulletin of the Japanese Society for the Science of Fish 44: 223-225. 
Citation: Mohapatra S, Chakraborty T, Kacem RH, Shimizu S, Matsubara T, et al. (2016) Starvation: An Alternate Measure to Improve Immunity and Physiology of Red Sea Bream During Edwardsiella Tarda Infection. J Aquac Res Development S2: 007. doi:10.4172/2155-9546.S2-007

35. Boujard T, Burel C, Medale F, Haylord G, Moisan A (2000) Effect of past nutritional history and fasting on feed intake and growth in rainbow trout Oncorhynchus mykiss. Aquatic Living Resources 13: 129-137.

36. Shoemaker CA, Klesius PH, Lim C, Yildirim M (2003) Feed deprivation of channel catfish, Ictalurus punctatus (Rafinesque), influences organosomatic indices, chemical composition and susceptibility to Flavobacterium columnare. Journal of Fish Diseases 25: 558-561.

37. Caruso G, Maricchiolo G, Micale V, Genovese L, Caruso R, et al. (2010) Physiological responses to starvation in European eel (Anguilla anguilla): effects on haematological, biochemical, non-specific immune parameters and skin structure. Fish Physiology and Biochemistry 36: 71-83.

38. Larsen DA, Beckman BR, Dickhoff WW (2001) The effect of low temperature and fasting during the winter on metabolic stores and endocrine physiology (insulin, insulin-like growth factor-I, and thyroxine) of coho salmon, Oncorhynchus kisutch. General and Comparative Endocrinology 123: 308-323.

39. De PN, Delgado MJ, Gancedo B, Alonso-Bedate M (2003) Changes in glucose glycogen, thyroid activity and hypothalamic catecholamines in tench by starvation and refeeding. Journal of Comparative Physiology B 173: 475-481.

40. Henmre GI, Lie O, Sundby A (1993) Dietary carbohydrate utilization in cod (Gadus morhua): metabolic responses to feeding and fasting. Fish Physiology and Biochemistry 10: 455-463.

41. Lee RJ, Marks LG (2009) Mycotic aspects of epizootic ulcerative syndrome (EUS) of Asian fishes. Journal of Fish Diseases 16: 169-184.

42. Khalil RH, Saad TT, Montaser L (2013) Some studies on Pseudomonas infection in experimentally infected Oreochromis niloticus. Journal of the Arabian Aquaculture Society 8: 205-215.

43. Adeyemi JA (2014) Oxidative stress and antioxidant enzymes in the African catfish, Clarius gariepinus, experimentally challenged with Escherichia coli and Vibrio fischeri. Fish Physiology and Boichemistry 40: 347-354.

44. Morales AE, Perez-Jimenez A, Hidalgo MC, Abellan E, Cardenete G (2004) Oxidative stress and antioxidant defences after prolonged starvation in Dentex dentex liver. Comparative Biochemistry and Physiology C 139: 153-161.

45. Vázquez-Medina JP, Crocker DE, Forman HJ, Ortiz RM (2010) Prolonged fasting does not increase oxidative damage or inflammation in post-weaned northern elephant seal pups. The Journal of Experimental Biology 213 2524-2530.

46. Deane EE, Woo NYS (2005) Modulation of b-actin, insulin-like growth factor 1 and glucose-6-phosphate dehydrogenase gene expression during vibriosis of sea bream, Sparus (=Rhabdosargus) sarba Forsskal. Journal of Fish Diseases 28: 593-601.

47. Mohapatra S, Chakraborty T, Shimizu S, Urasaki S, Matsubara T, et al. (2015) Starvation beneficially influences the liver physiology and nutrient metabolism in Edwardsiella tarda infected red sea bream (Pagrus major). Comparative Biochemistry and Physiology A 189: 1-10.

48. Zhang C, Hu J, Wang P, Wang G, Liu G, et al. (2004) Effects of B(a)P on $\mathrm{T}-\mathrm{AOC}$ in liver of Carassius auratu. Journal of Environmental Health 21: 324-326.

49. Feng G, Shi X, Huang X, Zhuang P (2011) Oxidative stress and antioxidant defenses after long-term fasting in blood of Chinese Sturgeon (Acipenser sinensis). Procedia Environmental Sciences 8: 469-475.

50. Dubovskiy IM, Martemyanov VV, Vorontsova YL, Rantala MJ, Gryzanova $\mathrm{EV}$, et al. (2008) Effect of bacterial infection on antioxidant activity and lipid peroxidation in the midgut of Galleria mellonella L. larvae (Lepidoptera, Pyralidae). Comparative Biochemistry and Physiology C 148: 1-5

51. Reece ST, Kaufmann SH (2008) Rational design of vaccines against tuberculosis directed by basic immunology. International Journal of Medical Microbiology 298: 143-150.

52. Yamasaki M, Araki K, Nakanishi T, Nakayasu C, Yoshiura Y, et al. (2013) Adaptive immune response to Edwardsiella tarda infection in ginbuna crucian carp, Carassius auratus langsdorfii. Veterinary Immunology and Immunopathology 153: 83-90.

53. Chettri JK, Raida MK, Kania PW, Buchmann K (2012) Differential immune response of rainbow trout (Oncorhynchus mykiss) at early developmental stages (larvae and fry) against the bacterial pathogen Yersinia ruckeri. Developmental and Comparative Immunology 36: 463-474.

54. Reyes-Cerpa S, Reyes-López F, Toro-Ascuy D, Montero R, Maisey K, et al. (2014) Induction of anti-inflammatory cytokine expression by IPNV in persistent infection. Fish and ShellfishImmunology 41: 172-182.

55. Reyes-Cerpa S, Reyes-López FE, Toro-Ascuy D, Ibañez J, Maisey K, et al. (2012) IPNV modulation of pro and anti-inflammatory cytokine expression in Atlantic salmon might help the establishment of infection and persistence. Fish and Shellfish Immunology 32: 291-300.

56. Mohanty BR, Sahoo PK (2010) Immune responses and expression profiles of some immune-related genes in Indian major carp, Labeo rohita to Edwardsiella tarda infection. Fish and Shellfish Immunology 28: 613-621.

57. Soest JJV, Stockhammer OW, Ordas A, Bloemberg GV, Spaink HP, et al (2011) Comparison of static immersion and intravenous injection systems for exposure of zebrafish embryos to the natural pathogen Edwardsiella tarda. BMC Immunology 12: 58

58. Philip AM, Jørgensen EH, Maule AG, Vijayan MM (2014) Tissue-specific molecula immune response to lipopolysaccharide challenge in emaciated anadromous Arctic charr. Developmental and Comparative Immunology 45: 133-140.

59. Philip AM, Daniel KS, Vijayan MM (2012) Cortisol modulates the expression of cytokines and suppressors of cytokine signalling (SOCS) in rainbow trout hepatocytes. Developmental and Comparative Immunology 38: 360-367.

60. Tian R, Hou G, Li D, Yuan TF (2014) A possible change process of inflammatory cytokines in the prolonged chronic stress and its ultimate implications for health. The Scientific World Journal.

61. Engelsma MY, Huising MO, van Muiswinkel WB, Flik G, Kwang J, et al. (2002) Neuroendocrine-immune interactions in fish: a role for interleukin-1. Veterinary Immunology andlmmunopathology 87: 467-479.

62. Cerezuela R, Fumanal M, Tapia-Paniagua ST, Mesguer J, Morinigo MA, et al (2012) Histological alterations and microbial ecology of the intestine in gilthead seabream (Sparus aurata L.) fed dietary probiotics and microalgae. Cell and Tissue Research 350: 477-489.

63. Brun NT, Ross NW, Boghen AD (2000) Changes in the electrophoretic profiles of gill mucus proteases of the eastern oyster Crassostrea virginica in response to infection by the turbellarian Urastoma cyprinae. Journal of Invertebrate Pathology 75: 163-170.

64. Esteban MA (2012) An overview of the immunological defenses in fish skin. ISRN Immunology 2012: 1-29.

65. Li L, Chen Y, Gibson SB (2013) Starvation induced autophagy is regulated by mitochondrial reactive oxygen species leading to AMPK activation. Cell Signalling 25: 50-65.
This article was originally published in a special issue, Current and Emerging Diseases/Disorders of Fish in Aquaculture handled by Editor(s). Prof. Patrick T.K. Woo, University of Guelph, Canada; Dr. Kenneth D. Cain, University of Idaho, USA. 